IZA DP No. 4232

Immigrant Child Poverty in Scandinavia:

A Panel Data Study

Taryn Ann Galloway

Björn Gustafsson

Peder J. Pedersen

Torun Österberg

June 2009 


\title{
Immigrant Child Poverty in Scandinavia: A Panel Data Study
}

\author{
Taryn Ann Galloway \\ Statistics Norway \\ Björn Gustafsson \\ Göteborg University and IZA \\ Peder J. Pedersen \\ University of Aarhus, SFI and IZA \\ Torun Österberg \\ Göteborg University
}

Discussion Paper No. 4232

June 2009

IZA

P.O. Box 7240

53072 Bonn

Germany

Phone: +49-228-3894-0

Fax: +49-228-3894-180

E-mail: iza@iza.org

Any opinions expressed here are those of the author(s) and not those of IZA. Research published in this series may include views on policy, but the institute itself takes no institutional policy positions.

The Institute for the Study of Labor (IZA) in Bonn is a local and virtual international research center and a place of communication between science, politics and business. IZA is an independent nonprofit organization supported by Deutsche Post Foundation. The center is associated with the University of Bonn and offers a stimulating research environment through its international network, workshops and conferences, data service, project support, research visits and doctoral program. IZA engages in (i) original and internationally competitive research in all fields of labor economics, (ii) development of policy concepts, and (iii) dissemination of research results and concepts to the interested public.

IZA Discussion Papers often represent preliminary work and are circulated to encourage discussion. Citation of such a paper should account for its provisional character. A revised version may be available directly from the author. 


\section{ABSTRACT \\ Immigrant Child Poverty in Scandinavia: A Panel Data Study}

Immigrant and native child poverty in Denmark, Norway and Sweden 1993 to 2001 is investigated using large sets of panel data. While native children face yearly poverty risks of less than 10 percent in all three countries and for all years investigated the increasing proportion of immigrant children with an origin in middle and low income countries have poverty risks that varies from 38 and up to as much as 58 percent. At the end of the observation period one third of the poor children in Norway have an immigrant origin, and that corresponding proportion is as high as about a half in Denmark as well as in Sweden. The strong overrepresentation of immigrant children from low and middle income countries when measured in yearly data is also found when applying a longer accounting period. We find that child poverty rates are generally high shortly after arrival to the new country, and typically decreases with years since immigration. Multivariate analysis shows that parents years since immigration and education affect risks of the number of periods in persistent poverty. While a native child is very unlikely to spend nine years in poverty, the corresponding risk for a child to a newly arrived immigrant from Turkey was found to be far from negligible. Much of the pattern is similar across the three countries but there are also some differences.

JEL Classification: F22, I32, J15

Keywords: child poverty, immigration, Denmark, Norway, Sweden

Corresponding author:

Björn Gustafsson

Department of Social Work

Göteborg University

P.O. Box 720

SE 40530 Göteborg

Sweden

Email: Bjorn.Gustafsson@socwork.gu.se 


\section{Introduction}

This paper aims to throw light on an important aspect of child poverty in rich northern European countries which has not attracted as much attention as we claim it deserves. Although the Scandinavian countries are in cross country studies generally found to have lower child poverty rates than most other rich countries (Chen and Corak, 2008), we will show that since the first half of the 1990s an ever larger proportion of poor children in Denmark, Norway and Sweden have an immigrant background from middle and low income countries. ${ }^{1}$ The main reason for this development is the vastly higher rates of child poverty among children with immigrant background vs native children in these countries combined with an increasing inflow of immigrants. Thus, child poverty in Scandinavia seems to be increasingly becoming an issue which is related to the particular circumstances of immigrant children from middle and low income countries.

Few studies examine the extent of immigrant child poverty and how it changes over time. For the U.S., van Hook et al (2004) analyzes cross-sectional data for the years 1969, 1979, 1989 and 1999 and reports that while immigrant children were less poverty prone than natives in 1969, the first year under analysis, immigrant poverty rates increased more rapidly than poverty rates among natives during the 1970s and especially so during the 1980s. In the 1990s child poverty rates for immigrants as well as natives peaked in 1997 and 1998 before falling in 1999 to a level slightly lower than in 1989. Children with Mexican ethnicity living in the U.S. have rather high poverty rates and the unfavourable development of immigrant child poverty rates could partly, but not fully, be attributed to compositional changes in immigrant families. Lichter et al (2005) analyzes the US developments between 1989 and 1999 in more detail and reports that increased maternal employment accounted for a substantial share of the decrease in immigrant child poverty rates in U.S. during the 1990s. Few studies have focused on immigrant child poverty in rich European countries. Bahalla and McCormick (2009, p 45) notes that there is no explicit mention or discussion of poverty among immigrant children in any EU documents and that one rarely comes across separate rates of child poverty for immigrants and non immigrants by different age-groups. Corak et al (2008) does, however, report child poverty rates for non-citizens in Germany being higher than for citizens and also finds that the upward trend in child poverty in Germany since the beginning of

\footnotetext{
${ }^{1}$ High income countries consist of the 25 EU countries, European Economic Area countries (Norway, Switzerland, Iceland), Oceania, North America and Japan. All other countries are in the group of middle and low income countries.
} 
the 1990s is linked to the situation of children in non-citizen households, particularly more recent arrivals.

Immigrant child poverty can be thought of as having a character in some respects different from poverty among native children. Just as with native child poverty, immigrant child poverty is linked to the situation of parents in the labour market of the host country. However, the labor market situation of immigrant parents is often quite different than for native parents. While immigrants all over the world tend to earn less than natives upon arrival in the host country, their economic situation typically improves substantially over time. ${ }^{2}$ Thus, one might expect that immigrant child poverty also decreases with years since parental migration. From such a perspective, one might therefore expect that the poverty faced by immigrant children is of a less persistent nature. However, if immigrant parents face barriers in the labour market and can not find gainful employment for long periods, immigrant child poverty may be more persistent and might even last the length of much of an immigrant child's childhood. It is of great relevance which of these two scenarios applies in reality to the situation for immigrant children in Scandinavia. However, in our literature search, we have found that very little effort has been made in studying such aspects of immigrant child poverty, most likely due to the lack of good micro-data suited to such a purpose.

Researchers interested in dynamic aspects of poverty have typically had to rely on available panel surveys. Having many advantages such data typically have difficulties in including immigrants in the sample frame, are troubled with non- response, and include only few immigrant children. The situation in the Scandinavian countries is in those aspects rather different. Having access to register data researchers do not face problems of non-response, can work with data covering many individuals as well as households and in the data most probably income and thereby poverty is more accurate measured than in surveys. This paper will illustrate that it is possible to study immigrant child poverty in Scandinavia in considerable detail, and probably with larger precision, than is typically the case for other countries.

The largely unanswered research questions related to immigrant child poverty are thus many and any attempts to answer such questions face a number of different challenges, because a thorough

2 See Barth et al. (2004), Chiswick et al. (2005), Hammarstedt and Shukur (2007), Husted et al. (2001) and Longva and Raaum (2003). 
study of immigrant child poverty places great demands on the data for the analysis. Firstly, any study of poverty based on a relative poverty line, as will be used here, requires detailed and quite comprehensive data on income for the general population. Secondly, in order to do justice to the extent of potential diversity in the immigrant population of any country, the size of the immigrant sample for a study of immigrant child poverty must be quite large. Finally, one would ideally wish to study child poverty from a dynamic or longer-term perspective; in the particular case of immigrant children, such a focus would aid in judging if immigrant children are disadvantaged compared to natives and whether such disparities persist or change over time. The rather comprehensive administrative data sources used here will allow us to meet those challenges for all three countries, Denmark, Norway and Sweden, and thus make it possible for us to study immigrant child poverty in more depth in those countries.

This study finds that, while native children face yearly poverty risks of less than 10 percent in all three countries and for all years investigated, the increasing proportion of immigrant children with an origin in middle and low income countries have poverty risks that varies from 38 and up to as much as 58 percent. At the end of the observation period approximately one-third of poor children in Norway are of immigrant origin and as much as about half of poor children in Denmark and Sweden have some form of immigrant background. The strong overrepresentation of immigrant children from low and middle income countries when measured in yearly data is also found when applying a poverty definition based on a longer accounting period. We find that child poverty rates are generally high shortly after arrival to the new country, but that poverty rates do typically decrease with years since (parental) immigration. However, for the cohort that arrived in 1993 as many as one-third of children from low and middle countries are still observed in poverty in Norway and Sweden eight years after their arrival in those countries; in Denmark the corresponding proportion was as high as three-fifths. Multivariate analysis confirms that parental years since immigration and education affect risks of the number of periods in persistent poverty. Highest are predicted child poverty rates when the parent is newly arrived and with low education. While a native child is very unlikely to spend nine years of his or her childhood in poverty, many immigrant children do face a very large risk of this occurrence. Finally, there is some indication that immigrant children with similar observable characteristics face a higher probability of spending multiple periods in chronic poverty in Denmark than in Norway or Sweden, although there are no clear differences for native children in the three countries. 
In the next section we provide some background information on immigration, the welfare states and labour markets in Denmark, Norway and Sweden. In Section 3 we present data for each of the three countries and report on how poverty is defined. In Section 4 we describe immigrant and native child poverty in the three countries both annually and on a 3 year basis meant to capture aspects of more persistent poverty. Section 5 reports results from multivariate analyses of the probability of different degrees of poverty persistence over the period of 9 years in the three countries. Finally we draw together the findings in a concluding discussion in Section 6. More detailed information on poverty rates, entry to and exit from poverty and regression results regarding persistent poverty are provided in the appendix.

\section{Background}

In recent decades both the flow and the stock of immigrants in the Scandinavian countries has changed very much, from a situation where a fairly low number of immigrants predominantly came from neighbouring countries to a situation where vastly larger flows are dominated by immigrants from poorer countries arriving as tied movers to guest workers living in the countries before the mid-1970s or as refugees (and their families). These developments in immigration occurred somewhat earlier in Sweden than in the two other countries. Sweden received during the 1950s, 1960s and 1970s many work migrants in addition to some streams of refugees, while corresponding immigration - both in absolute terms and relative to population size - was smaller in Denmark and Norway. A salient feature of all three countries during later years shared with some other north European countries is a relatively large influx of immigrants from low and middle income countries.

Furthermore, the most recent large inflows in Sweden occurred at a time where unemployment was high following a major cyclical downturn that began in the early 1990s and greatly influenced the labor market during much of the decade. Large inflows of immigrants also coincided with difficult economic conditions in both Norway and Denmark at the start of the 1990s, but, in contrast to Sweden, those two countries already experienced rapidly decreasing unemployment rates and improving labor market by the mid-1990s. Unemployment rates were, however, consistently higher in Denmark than in Norway during the 1990s. Thus, altogether the three countries have experienced 
similar immigration trends, but those developments coincided with different economic climates and experiences.

The Scandinavian countries are well known for their welfare states that in the sociological literature are typically considered to be of a particular type (Esping-Andersen, 1990, Arts and Gelissen, 2002). ${ }^{3}$ Many benefits are universal conditional only on residence in the country. The public sector is big and taxes relative to GNP are very high. The counterpart is a very high participation rate in the labour market for married women, making the two earner family dominant, not least in families with young children.

Common characteristics in the Nordic labour markets are a more compressed earnings structure compared with most other rich OECD countries and, in particularly, high wages at the lower end of the earnings distribution. As a consequence of this and perhaps for other reasons such as discrimination, immigrants to these countries may face barriers to entry into the labor market. Among the OECD countries in 1999-2000 OECD (2003) reports the lowest employment rate for male foreigners in Sweden. The employment rates for foreigners is slightly higher in Denmark than in Sweden, while Norway is one of the OECD countries with the highest employment rate for foreigners. Similarly, OECD (2003) also reports that the gap in employment rates for male foreigners and nationals is quite large in both Sweden and Denmark. ${ }^{4}$ In other words, lower employment rates for immigrants in Sweden and Denmark are not necessarily simply an artifact of generally lower general reemployment rates in the two countries.

\section{Data, Methods, and Definitions}

\subsection{Data}

We use administrative panel data for the period 1993 to 2001 from Denmark, Norway and Sweden to document yearly poverty rates as well as rates of persistent poverty among immigrant and native

\footnotetext{
${ }^{3}$ Finland also belongs to this class. However, compared to most other rich north European countries Finland has received few immigrants, one reason for not being included in the present study. According to Dumont and Lemaître (2005) the foreignborn population in Finland numbered less than 3 percent, while in Denmark and Norway it numbered 7 percent and in Sweden 12 percent. Those numbers can be compared with a rate of foreign born of 8 percent for United Kingdom, 10 percent in France and the Netherlands, 12 percen in United States and 13 percent for Germany.

${ }^{4}$ This could reflect differences in the propensity to or possibility of becoming a citizen which is assumed to be more easy in Sweden implying that the group of foreigners in statistical terms may differ from the same group in another country where citizenship is more difficult to achieve.
} 
children. We are particularly interested in how parental education and years since immigration affect risks of period of persistent poverty among immigrant children from low and middle income countries. We harmonise definitions across datasets for the three countries and, given the similarities in welfare state institutions and labor market structures in the three countries, we expect to find broad similarities in immigrant child poverty in Denmark, Norway and Sweden. However, due to the different economic conditions in the countries during the 1990s, we also expect to find some differences in trends in immigrants child poverty across the region.

The main data used in this study have been acquired from comprehensive administrative registers which exist for all three countries. Data from such administrative registers have been used extensively for research purposes and are generally considered to be of very high quality. Individual data from a number of registers are merged using a unique person identifier. Raaum and Røed (2003) provide an extensive discussion of the strengths of such data for research based in particular on the Norwegian case; however, similar tenets apply to the register data available for research purposes in the two other Scandinavian countries.

Whereas the Norwegian data encompasses the entire resident population, both immigrant and native, the Danish and Swedish data are in part based on representative samples of the two population groups drawn from administrative registers and constructed for research purposes. In particular, the Danish data consist of all immigrants and a 10 per cent representative sample of the whole population. Data originate in registers kept at Statistics Denmark. The Swedish data, taken from the Swedish Income Panel at the University of Gothenburg, also consists of two parts: a 1 percent random sample of native-born persons and a 10 percent random sample of the foreign-born. The latter was originally drawn from the population residing in Sweden in 1978, but has been updated with later arrivals. Both the native and foreign-born samples originate from the Register of the Total Population kept at Statistics Sweden. Data are highly comparable across countries regarding incomes and labour market status. The definition of the household used here can differ from household definitions in other studies from other countries based on data from surveys. In particular, register-based household definitions are generally based on family ties and cannot easily account for households which consist of several unrelated adults or family relations beyond the nuclear family. See for example Iceland (2000) for a discussion of poverty estimation with different household definitions for the US. 


\subsection{Defining Poverty}

Following common practice in the European Union (see Atkinson et al, 2002), we define a child as poor in a given year if equivalent disposable income is less than 60 percent of the median in the country of residence. The median is computed over all inhabitants in the country in question and recalculated for each year under study. We use the OECD equivalence scale to adjust household incomes to an individual specific level assigning the weight 1 to the first adult in the household, 0.7 to a second adult and 0,5 to each child.

\subsection{Persistent Poverty}

In part of the analysis, we shift the focus to the question of persistent poverty understood as poverty for a sequence of years. The issue is the extent to which the measure of poverty based on income from just one year is satisfactory for capturing the essential elements of why we are interested in poverty, be it among adults or children. Intuitively, an occasional short period of poverty does not necessarily entail extreme welfare losses nor would it seem a cause of great concern. For this reason, we wish to employ a somewhat different measure of 'persistent poverty' in order to better capture the intuition that it is poverty of a more prolonged nature which is the true focus of concerns associated with child poverty. In other words, we wish to provide a better basis for assessing the extent to which the poverty experienced by children - native or immigrant - may be prolonged and thus become a serious cause for worry in Scandinavia.

Income fluctuations can have a number of different effects on the nature of the poverty experienced by individuals and such income fluctuations can thus, in turn, affect summary statistics on poverty based on single year observations only. The inevitable fluctuations in income from one year to the next means that we will at any given time classify some generally well-off persons as poor and some generally poor persons as 'non-poor'. To help minimize such misclassifications, in later analysis we extend the income period used to determine poverty and define a relative poverty line based on three-year income in much the same manner as the poverty line based on income from one year. More specifically, the new poverty line is drawn at $60 \%$ of median three-year equivalent income and we refer to the resulting poverty classification as 'persistent poverty' in order to emphasize its more prolonged nature. More specifically, equivalent income is first determined for 
each year (based on the household composition in that year) with the traditional OECD equivalence scale. ${ }^{5}$ The equivalent yearly incomes thus calculated are then adjusted for inflation and summed up over a three-year period. The persistent poverty line is then defined as $60 \%$ of the median of the three-year incomes in the population.

The choice of a three-year period is somewhat arbitrary, but does help to eliminate some of the above-mentioned weaknesses due to income fluctuations. In addition, with data from the nine-year period 1993-2001 and a persistent poverty definition based one three-year income, we are able to construct measures of persistent poverty for three successive three-year periods - 1993-1995, 19961998 and 1999-2001. We are thus able to uncover and discuss trends, i.e. changes in persistent poverty during the period. Finally, we are still able to discuss topics such as the extent and duration of persistent poverty in much the same manner as we do with yearly poverty; in other words, we are able to discuss the extent to which children experience one period or several periods of persistent poverty.

\subsection{Definition of Relevant Groups according to Immigrant Background}

In the analysis we distinguish between three different groups of children according to immigrant background. Children are grouped as having a background from a middle or low income country (MLIC) if one or both parents are born in a MLIC. Children are grouped as native if one or both parents are both in the Scandinavian country in question. The final group consist of all other children with some sort of foreign background. These includes cases in which one or both parents born were born in another high income country (HIC) country.. Note that the definition of the groups is based on the parents' origin rather than where the child is born; thus, we generally include children born to foreign parents in the respective countries. ${ }^{6}$

\section{Descriptive Survey of Scandinavian Child Poverty, 1993 - 2001.}

In this section we present a brief survey of the trends in child poverty in our three countries over the period in focus, with main emphasis on the ethnic background of the children and the cross-country differences. The descriptive survey is followed by a multivariate analysis in Section 5, which aims

\footnotetext{
${ }^{5}$ Note furthermore that in this construction we are forced to focus only on those children receding in the country and under the age of 18 for the entire three-year period in question.

${ }^{6}$ Table 2, which reports poverty rates for newly arrived cohorts of immigrants is one exception which focusly exclusively on children who were born abroad and themselves immigrated to Scandinavia.
} 
to uncover some of the underlying determinants of the number of 3-year periods in persistent poverty, as defined below, for immigrant and native born children separately for each of the three countries.

\subsection{Some Basic Facts and Figures on Yearly Poverty}

Figure 1 presents yearly poverty rates for two of the three main groups of childen - children with no immigrant background (natives) and children with immigrant background from middle and low income countries (MLIC) - in the three countries for each of the years 1993-2001. More detailed results, including those for children with backgrounds from high income countries (HIC) and for children as a whole can be found in Table A.1 in the Appendix.

Figure 1. Child poverty rates in Norway, Sweden and Denmark. Natives and immigrants from middle and low income countries, 1993-2001.

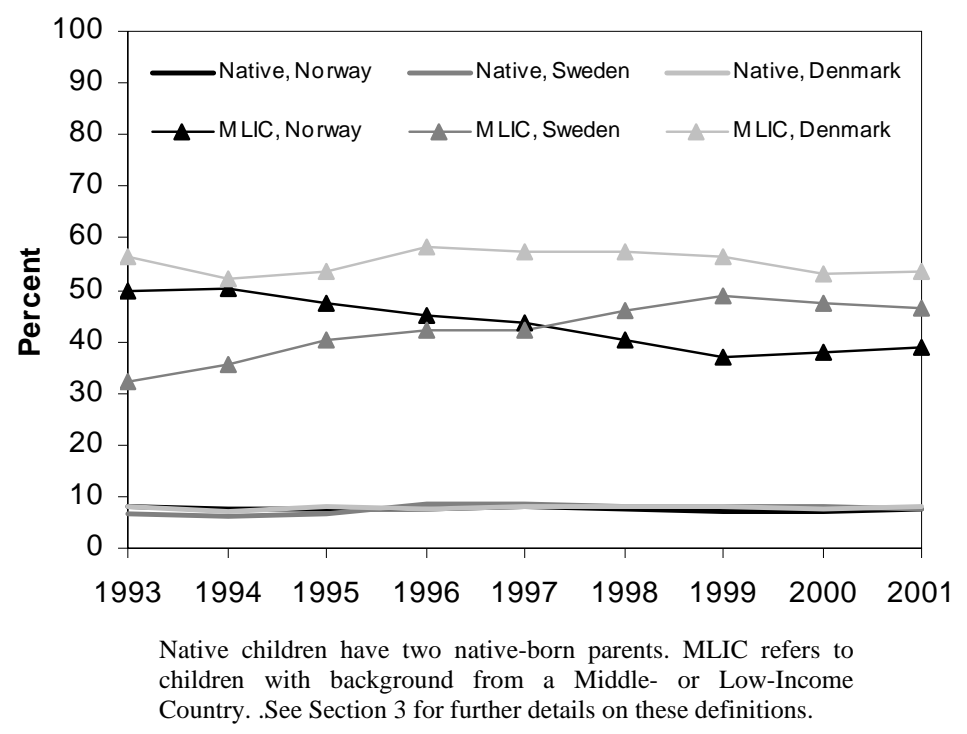

The most striking feature of Figure 1 is by far the large difference in poverty rates for the two groups of children. For native children the cross-country differences are quite small; their rates of poverty hover around 7 to 8 percent. There is much more variation in the poverty rates for MLIC children in the three countries. The level is highest in Denmark with between 50 and 60 percent of children in this group at or below the relative poverty line. While the poverty rate in Norway declines with some 10 percentage points for this group, we see the opposite pattern in Sweden with an increase in the poverty rate of nearly 20 percentage points up to a level close to Denmark's at the 
end of the period. These differences in levels and profiles can be expected to reflect the overall impact from underlying differences in a number of factors, i.e. countries of origin for the immigrants, duration of residence in the host country, the general economic climate in the host country, and public sector programs for benefits to families.

Figure 2 provides some supplementary information on unemployment rates in the three countries since 1980 as an aid to interpreting the changes in poverty rates relative to general economic conditions (in the labor market). There was a rise in unemployment in all three countries just prior to the start of the period for this study, but the increase was most pronounced in Sweden. In addition, whereas unemployment rates start to decline in Denmark and Norway roughly at the start of the period for this study, unemployment remains high in Sweden for much longer. The decline in child poverty rates both for native and immigrant children in Norway seems to largely coincide with the decline in unemployment; in Sweden, high unemployment appears to be accompanied by a rise in child poverty, both for natives and immigrants. However, whereas child poverty start to decline for native children as the overall unemployment rates fall, child poverty for MLIC child continues to rise for many years even as unemployment falls dramatically in Sweden. In Denmark, on the other hand, the level, both for native and MLIC children does not show any direct relation to the cyclical profile of the Danish economy. General economic conditions, as illustrated by changes in unemployment rates, thus appear to have different effects on child poverty in the three countries during this period and, especially in Sweden, the relationship between unemployment and child poverty differs for native children on the one hand and immigrant children on the other.

Figure 2. Unemployment Rates in Denmark, Norway and Sweden. 1980-2003. 


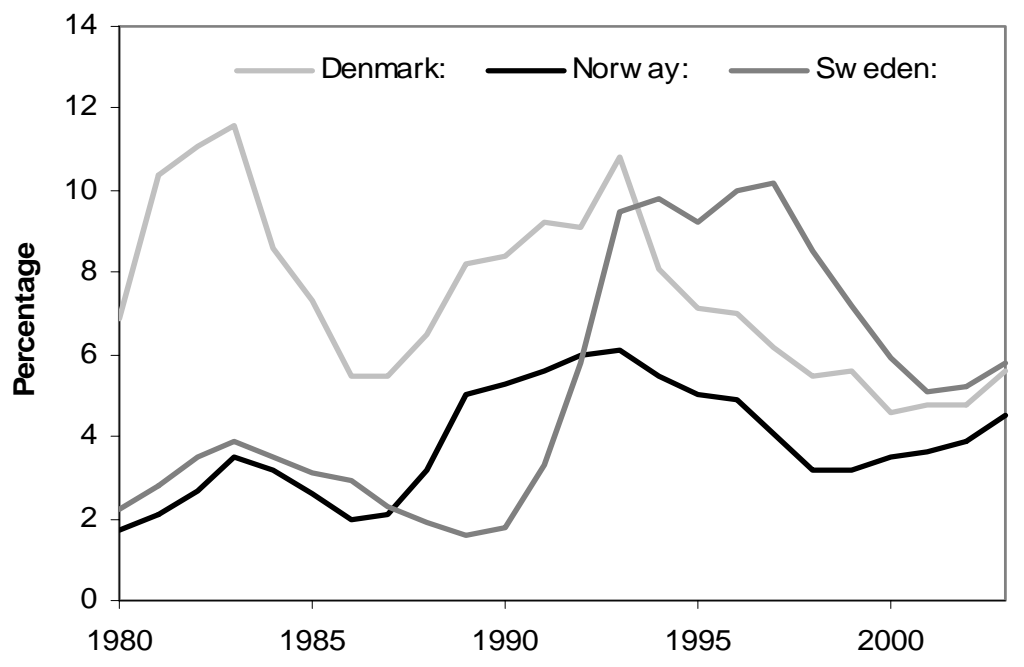

Source: OECD Labour Force Statistics

In Table 1 we show the composition of all children and poor children by immigration category. The share of children with immigrant background is significantly higher in Sweden than in Denmark and Norway in 1993. The share of children with some form of immigrant background also clearly increases in all three countries during the period. In Denmark, the share of immigrants from MLIC is higher than the HIC share whereas the opposite is the case for Sweden and Norway. Note in particular that over 25 per cent of children in Sweden have some form of immigrant background by the end of the period we study.

Table 1. Composition of children overall and of poor children by immigration category in the first and the last year of the study. Per cent .

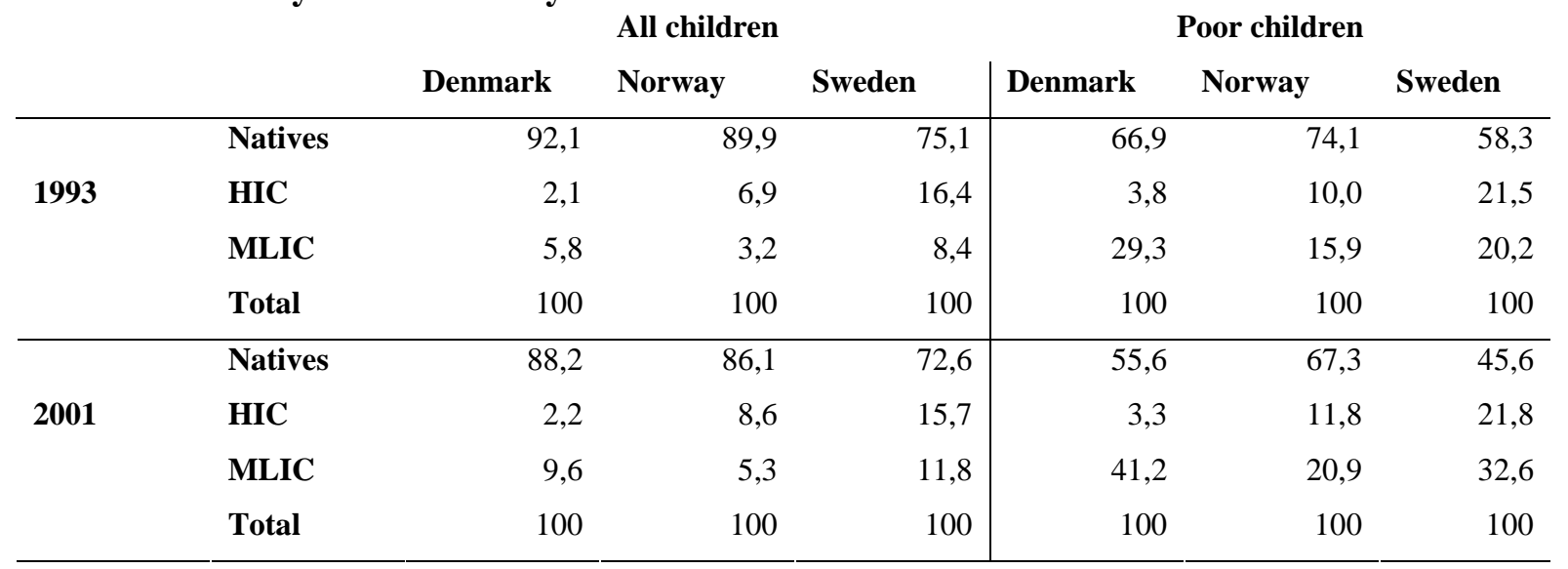


Native children make up ever smaller proportions of poor children over time in these countries, as the last three columns of Table 1 illustrate. By 2001, more than half of the poor children in Sweden have some form of immigrant background; approximately one-third of the poor children have MLIC backgrounds. In Denmark over 40 percent of the poor children have MLIC backgrounds. Even in Norway, where MLIC children make up just over 5 percent of all children, over one-fifth of children in poverty have MLIC background. Clearly, poverty among immigrant children is already a major aspect of child poverty in all three countries and the relevance of immigrant child poverty in influencing the pictures of child poverty in these countries is also on the rise.

\subsection{Poverty Entry and Exit Rates}

In order to gain some greater understanding of the general dynamics involved in child poverty in these countries Figures 3 and 4 present child poverty entry and exit rates for native and MLIC children. (Tables A.2 and A.3 in the Appendix provides more detailed information on these rates including the corresponding rates for HIC children.) More specifically, Figure 3 presents the rates of children who entered poverty given that they were not poor in the preceding year. Figure 4 indicates the percentage of children who exited poverty in a particular year given that they were poor the preceding year. Clearly, the higher rates of poverty among MLIC children in these countries is attributable to both higher entry rates and lower exit rates.

Figure 3. Rates of Entry into Child Poverty by Immigrant Category in Norway, Sweden and Denmark. 1993-2001.

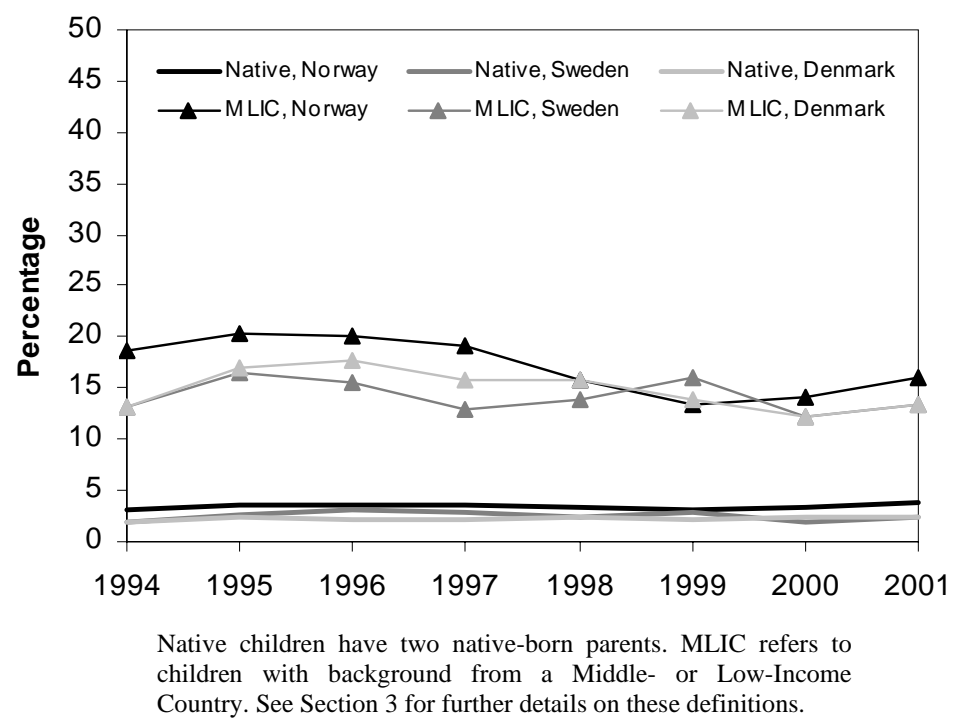


Except for a marked fall and subsequent rise in exit rates for native children in Sweden during this period, the entry and exit rates for native children are quite similar in all three countries. Less than 5 percent of native children enter into a new spell of poverty each year and approximately 40-45 percent of native children who are in poverty in one year exit poverty in the following year during the period studied here. Thus, poverty for native children in these countries does not seem to be of a particularly persistent nature.

Note in particular that while exit rates for native Swedish children eventually increased as unemployment fell in Sweden, exit rates for MLIC children in Sweden largely remained at a lower level despite improving labour market conditions in the country in the late 1990s. Thus, the reason for the continued increase in poverty rates for MLIC children in Sweden throughout the 1990s seems, at least in part, to be attributable to an increase in poverty persistence for that group.

Figure 4. Rates of Exit from Child Poverty by Immigrant Category in Norway, Sweden and Denmark. 1993-2001.

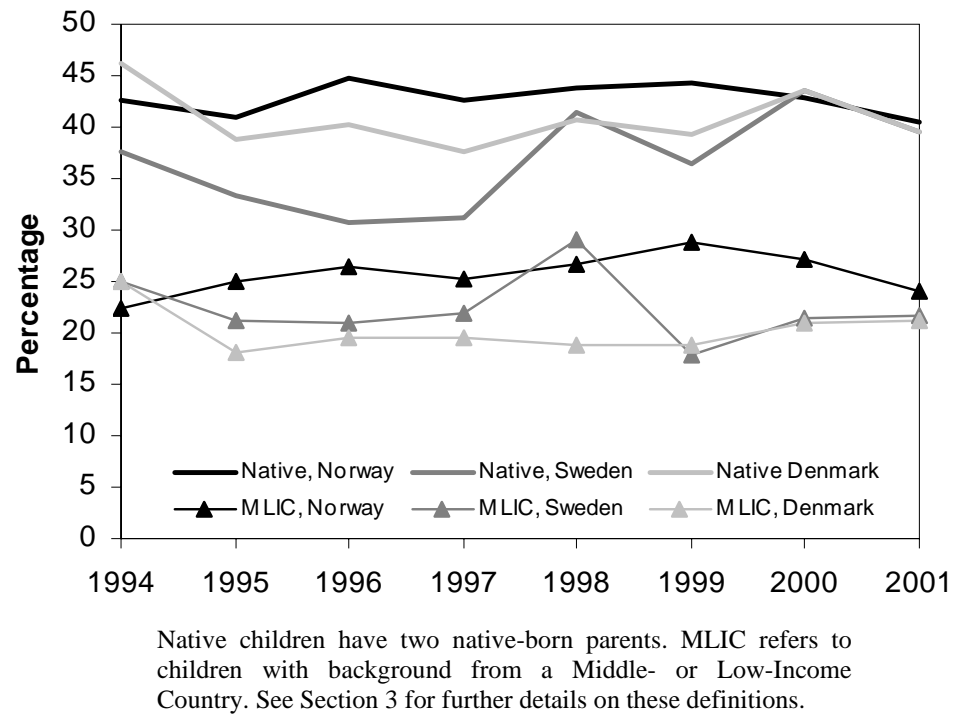

Entry rates for MLIC children in Denmark are roughly similar to the corresponding rates in Norway and Sweden, but poverty exit rates are consistently as low as or lower than corresponding rates in the other countries. Thus, it would seem that part of the reason for higher poverty rates for MLIC children in Denmark compared to Norway and Sweden is due to somewhat greater poverty persistence for those children in Denmark. As economic conditions improved in Norway, they 
seemed to be accompanied by a decline in poverty entry rates and a rise in poverty exit rates for both native and MLIC children, as might be expected.

\subsection{Poverty Rates for Recent Arrival Cohorts of Immigrant Children}

Previous studies of poverty among adult immigrants in Scandinavia (Galloway and Aaberge, 2005, Blume et al, 2007, Hansen and Wahlberg, 2009 ) suggest that a longer period of residence in the host country is associated with lower poverty rates; the main forces behind this relationship are assumed to be the process of adjustment and integration in terms of language and skills in the labor market. Although one would thus assume that a similar pattern exists for immigrant children in relation to their parents' duration of residence, this need not be the case. Families with children might face particular difficulties and challenges in adjusting to the host country. Furthermore, the speed of the adjustment, i.e. the length of time needed for a truly significant decline in the probability of poverty, is particularly relevant in the context of children; a prolonged period of adjustment associated with economic hardship might, in fact, encompass a large part of a child's formative years. This, in turn, may affect that child's educational attainment and own adjustment in the host country.

In order to provide some initial insight into this issue, Table 2 presents poverty rates for newly arrived immigrant children from Middle- and Low-Income Countries. ${ }^{7}$ We follow each yearly arrival cohort for the years after immigration to the country. Thus, the 1993 arrival cohort is followed for the years 1994-2001, whereas the 1994 arrival cohort is studied for the years 19952001, etc. If we first follow separate arrival cohorts in the year after their arrival, we see that the poverty rates generally fall quite markedly in both Norway and Sweden; thus, longer periods of residence do seem to be associated with lower poverty rates for newly arrived immigrant children. Note, however, that poverty rates for these immigrant children are still very high after many years in the country, i.e. poverty rates for newly arrived MLIC children cannot be said to quickly converge to rates similar to natives’.

In Denmark, initial poverty rates are higher and the fall in the years after arrival is much slower than in the two other countries. The only exception to this pattern is the 1995 arrival cohort for

\footnotetext{
${ }^{7}$ Note that newly arrived immigrants could not be included in Figure 3 or 4, since entry and exit rates are defined based on poverty status in the previous period. Newly arrived immigrants cannot be said to have experienced a previous period before the first year in the country.
} 
which the initial level is as high as for the other cohorts but the fall in poverty rates is much more pronounced. The most probable explanation for this exception that that the 1995 arrival cohorts was dominated by refugees from Bosnia and that (the parents of) those arrivals entered the labour market much faster than their counterparts from other countries.

Table 2 also illustrates another relevant point; the starting poverty rates, i.e. the poverty rates in the first full year after arrival, as well as the poverty rates for subsequent years vary for the different arrival cohorts. There are two possible explanations for this. First, the composition of the different arrival cohorts in terms of education, skills, age, ethnic background, etc. might simply be different, thus leading to different poverty rates. Second, the differences in poverty rates might also reflect economic conditions during the initial phase in the country. More specifically, immigrants entering the country during good economic times will be expected to have better opportunities to integrate into the labor market and in general gain a foothold in the economy of the host country; immigrants entering during economic difficulties might struggle in this regard.

Table 2. Child Poverty Rates for Children from Middle- and Low-Income Countries (MLIC) Age 0-17 Years by Arrival Cohort. 1993-2001. Denmark, Norway and Sweden. Percent.

\begin{tabular}{|c|c|c|c|c|c|c|c|c|}
\hline \multirow[b]{2}{*}{ Arrival cohort } & \multicolumn{8}{|c|}{ Poverty Rate for Arrival Cohort in Year } \\
\hline & 1994 & 1995 & 1996 & 1997 & 1998 & 1999 & 2000 & 2001 \\
\hline \multicolumn{9}{|l|}{ Denmark } \\
\hline 1993 & 73,6 & 71,3 & 73,0 & 72,3 & 72,4 & 67,8 & 62,8 & 60,6 \\
\hline 1994 & & 75,0 & 76,0 & 75,7 & 74,9 & 71,7 & 65,7 & 62,4 \\
\hline 1995 & & & 72,3 & 62,8 & 54,6 & 48,4 & 40,8 & 36,7 \\
\hline 1996 & & & & 79,4 & 76,3 & 73,8 & 67,6 & 65,0 \\
\hline 1997 & & & & & 75,9 & 75,5 & 69,5 & 69,5 \\
\hline 1998 & & & & & & 81,2 & 76,7 & 73,1 \\
\hline 1999 & & & & & & & 75,5 & 74,8 \\
\hline 2000 & & & & & & & & 79,6 \\
\hline \multicolumn{9}{|l|}{ Norway } \\
\hline 1993 & 63,2 & 50,1 & 47,7 & 44,6 & 40,1 & 35,2 & 33,6 & 34,4 \\
\hline 1994 & & 49,2 & 43,9 & 44,2 & 40,5 & 35,2 & 35,2 & 36,2 \\
\hline 1995 & & & 47,6 & 42,3 & 41,5 & 37,4 & 36,4 & 38,4 \\
\hline 1996 & & & & 46,1 & 39,6 & 35,3 & 37,2 & 38,4 \\
\hline 1997 & & & & & 42,0 & 34,7 & 34,9 & 38,2 \\
\hline 1998 & & & & & & 41,0 & 33,5 & 36,7 \\
\hline 1999 & & & & & & & 52,9 & 44,6 \\
\hline 2000 & & & & & & & & 47,1 \\
\hline \multicolumn{9}{|l|}{ Sweden } \\
\hline 1993 & 64,2 & 60,8 & 57,5 & 52,5 & 45,1 & 44,2 & 38,9 & 35,5 \\
\hline 1994 & & 69,1 & 63,9 & 57,0 & 49,1 & 48,2 & 43,4 & 40,0 \\
\hline 1995 & & & 71,5 & 63,0 & 52,4 & 50,8 & 43,4 & 39,0 \\
\hline 1996 & & & & 68,1 & 54,3 & 51,5 & 44,6 & 39,8 \\
\hline 1997 & & & & & 62,4 & 56,6 & 48,4 & 43,5 \\
\hline 1998 & & & & & & 69,8 & 55,8 & 49,1 \\
\hline 1999 & & & & & & & 64,3 & 56,8 \\
\hline 2000 & & & & & & & & 67,8 \\
\hline
\end{tabular}


Native children have two native-born parents. MLIC refers to children with background from a Middle- or Low-Income Country. See Section 3 for further details on these definitions.

Poverty rates in the first full year after arrival are fairly constant, i.e. in Denmark varying between 70 and 80 per cent and in Sweden varying between 60 and 70 per cent. After an initial drop in Norway, the first full year level also stabilizes, in this case between 40 and 50 per cent. The crosscountry differences most like reflect the more favourable economic situation in Norway. The profile over time in the first year poverty rates does however not seem to reveal any short run dependency on the cyclical situation at the time of entry. Looking at the decline in absolute terms across the cohorts from year of entry until the last year of observation we find clearly stronger declines in Sweden while the fall in absolute terms is at the same level in Denmark and Norway in most of the period. Hence, basic insights from descriptive analysis suggests that the duration of residence interacts with a number of other factors to have an impact on poverty rates among immigrant children.

\subsection{Persistent Poverty}

In this section we shift the focus of the analysis to the measure of persistent poverty defined in Section 3.3. Table 3 presents the rates of persistent poverty among children in Scandinavia as a whole and by immigration category. The same basic trends as discussed above for annual poverty rates, i.e. a fairly constant level in Denmark, decline in child poverty rates in Norway and a rise in rates in Sweden, are reproduced in the rates of persistent poverty for the period 1993-2001. Thus, the increase in annual poverty rates in Sweden is not solely due to short-term experiences of poverty.

Table 3 Persistent Poverty among Children in Denmark, Norway and Sweden by Immigration Category. 1993-2001. Percent.

1993-1995 1996-1998 1999-2001

Denmark

\begin{tabular}{|c|c|c|c|}
\hline Natives & 7,8 & 8,2 & 7,8 \\
\hline HIC & 17,3 & 18,4 & 16,3 \\
\hline MLIC & 59,0 & 63,1 & 58,4 \\
\hline All & 11,0 & 12,6 & 12,3 \\
\hline
\end{tabular}

Norway

Natives

6,2

6,3

5,9

HIC

10,4

10,1

10,1 


\begin{tabular}{lrrr} 
MLIC & 47,4 & 41,7 & 34,6 \\
\hline All & 8,3 & 8,3 & 7,8 \\
\hline Sweden & & & \\
$\quad$ Natives & 5,4 & 7,1 & 6,2 \\
HIC & 11,0 & 13,6 & 14,6 \\
MLIC & 34,0 & 42,6 & 44,8 \\
\hline All & 8,6 & 11,4 & 11,7 \\
\hline Native children have two native-born parents. MLIC refers to children with background from a Middle- or Low-Income Country. HIC \\
refers to children with background from a High-Income Country. See Section 3 for further details on these definitions.
\end{tabular}

While the concept and definition of persistent poverty discussed in Section 3.3 above already attempts to capture the essential feature of prolonged poverty as the true topic of interest, we are also able to discuss the extent to which poverty is more chronic in the sense that persistent poverty -- poverty defined over a three-years income period -- is experienced in more than just one threeyear period. Figure 5 presents the distribution of children age 0-9 years in 1993 by immigration category in Denmark, Norway and Sweden according to the number of 3-year periods they experienced persistent poverty in the period 1993-2001. The differences between native and immigrant children are once again quite pronounced. About 90 per cent of native children experienced no persistent poverty at all in the period, whereas more than half of MLIC children experienced at least one period of persistent poverty. Furthermore, multiple periods of persistent poverty were very rare among native and HIC children. In all three countries 15 - 20 per cent of MLIC children experienced two periods in persistent poverty. In contrast, 40 per cent of MLIC children experienced persistent poverty in three periods in Denmark with the corresponding numbers being slightly above 20 per cent in both Norway and Sweden. In Section 5 we investigate in more detail some determinants behind these differences. This could relate to a number of factors, i.e. the country of origin, parents' education, duration of residence in the host country etc. Note, however, in particular that the composition of immigrants according to ethnic background can still be quite different between the host countries. Note also further that the criterion for being included in Figure 5 is that the child was younger that 18 throughout the period $1993-2001$. This selection to a fraction of the stock of immigrants in 1993 implies that arrivals after this year are excluded and that a major part of those included - here as well as in the regression analyses below - are arrivals up to 1993. The consequence of this for the evaluation of the cross country results is that the majority of the included Danish sample arrived to a situation with unemployment rates significantly higher than in Norway and even higher than in Sweden with full employment until the last two years before 1993. 


\section{Figure 5. Distribution of Children by Number of Periods of Persistent Poverty By Immigrant Category in Denmark, Norway and Sweden.}
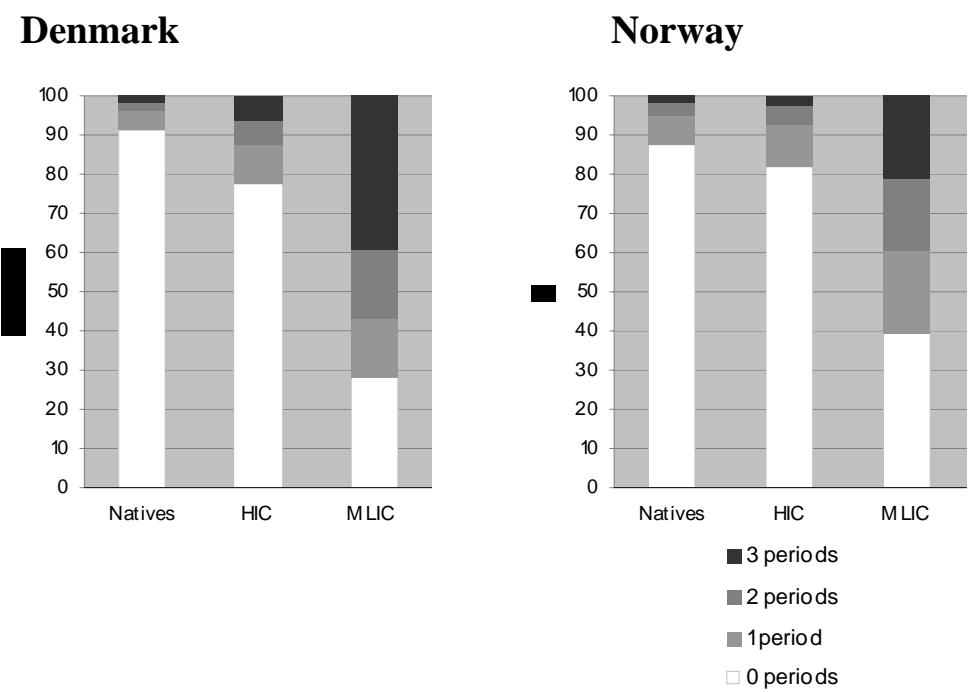

Sweden

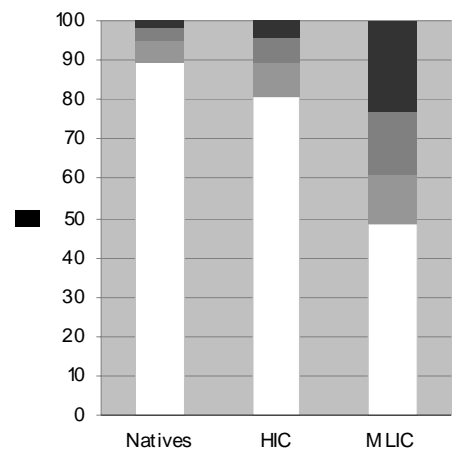

Native children have two native-born parents. MLIC refers to children with background from a Middle- or Low-Income Country. See Section 3 for further details on these definitions.

\section{Underlying Features of Persistent Poverty among Immigrants in Scandinavia}

\subsection{Focus of the Regression Analysis}

The regression analysis in this section aims to give further insights into the main features of the experience of persistent child poverty in Scandinavia with particular emphasis on the differences between native children and immigrant children from Middle- and Low-Income Countries. The basic descriptive analyses presented in the previous sections suggest that there are two main differences in the child poverty for immigrant vs. native children in the Scandinavian countries. First, the incidence of poverty is much higher for MLIC immigrant children. Secondly, the poverty experienced by MLIC children is of a much more prolonged nature. Furthermore, the use of a measure of persistent poverty based on income from a three-year period helped us to more elegantly represent and illustrate these differences. Thus, we wish to continue to work within this framework and further elaborate on the features of the experience of persistent poverty for children in Scandinavia. To this end, we use a multinomial logit framework to estimate the probability of experiencing 1, 2 or 3 periods of persistent poverty during the period 1993-2001. 
A number of explanatory variables are used to help uncover the extent to which observed characteristics are associated with a higher incidence and duration of persistent poverty during the period. These include the age of the (eldest) parent, parents' education, the local unemployment rate (except for Denmark, where such a variable was unavailable), various family or household characteristics, as well as the parents' duration of residence in the host country. ${ }^{8}$ We have attempted to define and code variables in as comparable a manner as possible for the countries; there will, however, always remain small differences due to the structure of societal institutions and data collection. Focus is limited to the analysis of native and MLIC children age 0-9 years in 1993 to ensure that the estimations include the same group of children throughout the period; separate regressions for the two groups (for each host country) are performed in order to allow for flexibility in the parameter estimates for the observed characteristics. The composition of MLIC immigrant children in terms of ethnic background or country of origin is very different in the three countries; hence, variables on the ethnic origin of immigrant children are based on the most relevant immigrant countries or ethnic categories in each specific (host) country. There do, however, exist immigrant children in sufficient number from some of the same countries in both Denmark, Norway and Sweden and these will be of particular interest for the analyses presented in this section.

\subsection{Parents' Duration of Residence and the Probability of Persistent Poverty}

The parameter estimates from the multinomial logit models of the probability of multiple periods of persistent poverty are presented in Tables A.4 - A.9 in the Appendix. Tables $4-6$ below present estimates of the risk of experiencing multiple periods of persistent poverty for selected immigrant groups in each of the three countries calculated from the parameter estimates. Particular emphasis is given to the parents' duration of residence in the country in order to indicate the extent to which differences between native and immigrant children decrease with increased (parental) experience in the country. In general, large differences between the risk of persistent poverty between immigrant and native children generally remain even if the parents of the immigrant child have been in the country for many years.

Comparing the poverty situation for Turkish immigrants in all three countries, we find that the estimated probability of none or only one period of persistent poverty for a Turkish child with a long family history in the host country (parents' duration of residence equal to or greater than 9

\footnotetext{
${ }^{8}$ Note that these variables are generally measured at the start of the period, i.e. in 1993. Thus, parents' duration of residence, age or education is as of 1993.
} 
years) is approximately 85 per cent in Norway, 73 percent in Sweden and 65 percent in Denmark. A similar pattern of estimated differences between the different countries is also apparent for Iranian immigrants in the three countries: slightly more than 90 percent of Iranian children in Norway experience at most one period of persistent poverty, whereas the corresponding probabilities for Sweden and Denmark are roundly 85 and 70 percent, respectively.

In contrast, it is highly probable that a native child $0-9$ years old in 1993 avoids experiencing persistent poverty. In Denmark the probability for a native child of having experienced no in persistent poverty is 97,1 per cent, in Norway it is 94,8 per cent and in Sweden it is 95,1 per cent. This can be compared to a child with newly arrived parents from Turkey. For her or him the predicted probability of experiencing no persistent poverty is at much lower levels: 20,2 per cent in Denmark, 30,5 per cent in Norway and 41,4 per cent in Sweden.

Table 4. Estimated Risk of Multiple Periods of Persistent Child Poverty for Selected Ethnic Groups by Duration of Residence. Denmark.

For a reference child*

Native children

Turkish background and parents in the country for:

1-2 years

3-4 years

5-6 years

7-8 years

$9+$ years

Iranian background and parents in the country for:

$\begin{array}{ll}1-2 \text { years } & 0,2031 \\ \text { 3-4 years } & 0,2916 \\ \text { 5-6 years } & 0,3739 \\ 7-8 \text { years } & 0,3749 \\ 9+\text { years } & 0,4474\end{array}$

Former Yugoslavia background and parents in the country for:

1-2 years

3-4 years

5-6 years

7-8 years

$9+$ years

Sri Lanka background and parents in the country for:

$$
\text { 1-2 years }
$$

0,3190

0,4003

0,5193

0,6112

0,6114

0,6809

0,2897
0,2532

0,2342

0,2107

0,2045

0,1917

0,3390

0,3120

0,2799

0,2727

0,2541

0,2347

0,1952

0,1608

0,1563

0,1359
0,2949

0,2564

0,2284

0,2281

0,1964

0,2776

0,2402

0,2133

0,2140

0,1830

0,1891

0,1478

0,1206

0,1206

0,0963
0,2495

0,2173

0,1853

0,1932

0,1615
3 periods 0,0019 


$\begin{array}{lllll}\text { 3-4 years } & 0,4307 & 0,2507 & 0,2033 & 0,1153 \\ \text { 5-6 years } & 0,5230 & 0,2130 & 0,1710 & 0,0929 \\ \text { 7-8 years } & 0,5242 & 0,2075 & 0,1715 & 0,0968 \\ 9+\text { years } & 0,5979 & 0,1847 & 0,1402 & 0,0772\end{array}$

* The reference child is defined as having parents with some secondary education, eldest parent age 40.

Table 5. Estimated Risk of Multiple Periods of Persistent Child Poverty for Selected Ethnic Groups by Duration of Residence. Norway.

For a reference child*

\begin{tabular}{lcccc} 
& \multicolumn{4}{c}{ Risk of Experiencing Chronic Poverty in: } \\
Native children & $\mathbf{0}$ periods & 1 period & 2 periods & 3 periods \\
& 0,9477 & 0,0367 & 0,0117 & 0,0039 \\
\cline { 2 - 5 } Turkish background and parents & & & & \\
in the country for: & & & & 0,1065 \\
1-2 years & 0,3053 & 0,3759 & 0,2123 & 0,1096 \\
3-4 years & 0,3845 & 0,3043 & 0,2016 & 0,0891 \\
5-6 years & 0,4517 & 0,2878 & 0,1713 & 0,0963 \\
7-8 years & 0,5193 & 0,2650 & 0,1193 & 0,0563 \\
9 + years & 0,6635 & 0,1836 & 0,0966 &
\end{tabular}

Iranian background and parents in the country for:

$\begin{array}{lllll}\text { 1-2 years } & 0,4416 & 0,3492 & 0,1580 & 0,0512 \\ \text { 3-4 years } & 0,5340 & 0,2714 & 0,1440 & 0,0505 \\ \text { 5-6 years } & 0,5988 & 0,2451 & 0,1168 & 0,0393 \\ \text { 7-8 years } & 0,6633 & 0,2174 & 0,0784 & 0,0409 \\ 9+\text { years } & 0,7807 & 0,1388 & 0,0585 & 0,0220\end{array}$

Chilean background and parents in the country for:

$\begin{array}{lllll}\text { 1-2 years } & 0,4710 & 0,3702 & 0,1176 & 0,0412 \\ \text { 3-4 years } & 0,5666 & 0,2862 & 0,1067 & 0,0405 \\ \text { 5-6 years } & 0,6280 & 0,2554 & 0,0855 & 0,0311 \\ \text { 7-8 years } & 0,6874 & 0,2239 & 0,0567 & 0,0320 \\ 9+\text { years } & 0,7998 & 0,1413 & 0,0418 & 0,0170\end{array}$

Somalian background and parents in the country for:

$\begin{array}{lllll}\text { 1-2 years } & 0,3952 & 0,3832 & 0,1556 & 0,0660 \\ \text { 3-4 years } & 0,4862 & 0,3030 & 0,1444 & 0,0663 \\ \text { 5-6 years } & 0,5522 & 0,2771 & 0,1186 & 0,0521 \\ \text { 7-8 years } & 0,6170 & 0,2479 & 0,0803 & 0,0548 \\ 9+\text { years } & 0,7457 & 0,1625 & 0,0615 & 0,0303\end{array}$

* The reference child is defined as having parents with some secondary education, eldest parent age 40, local unemployment equal to the national rate in 1993.

Table 6. Estimated Risk of Multiple Periods of Persistent Child Poverty for Selected Ethnic Groups by Duration of Residence. Sweden.

For a reference child* 


\section{Native children}

Turkish background and parents in the country for:

1-2 years

3-4 years

5-6 years

7-8 years

$9+$ years

Iranian background and parents in the country for:

1-2 years

3-4 years

5-6 years

7-8 years

$9+$ years

Chilean background and parents

in the country for:

1-2 years

3-4 years

5-6 years

7-8 years

$9+$ years

Somalian background and

parents in the country for:

1-2 years

3-4 years

5-6 years

7-8 years

$9+$ years

Risk of Experiencing Persistent Poverty in:

\begin{tabular}{cccc} 
0 periods & 1 period & 2 periods & 3 periods \\
\hline 0,9511 & 0,0299 & 0,0121 & 0,0069
\end{tabular}

$\begin{array}{lccc}0,4109 & 0,2507 & 0,2344 & 0,1041 \\ 0,5047 & 0,2174 & 0,185 & 0,0929 \\ 0,5106 & 0,2039 & 0,1807 & 0,1048 \\ 0,5913 & 0,1731 & 0,155 & 0,0807 \\ 0,6149 & 0,1219 & 0,1962 & 0,0670\end{array}$

$\begin{array}{llll}0,5639 & 0,2283 & 0,1700 & 0,0378 \\ 0,6543 & 0,1870 & 0,1268 & 0,0319 \\ 0,6638 & 0,1759 & 0,1241 & 0,0361 \\ 0,7305 & 0,1419 & 0,1012 & 0,0264 \\ 0,7524 & 0,0990 & 0,1269 & 0,0217\end{array}$

$\begin{array}{llll}0,7801 & 0,1629 & 0,0432 & 0,0138 \\ 0,8362 & 0,1233 & 0,0298 & 0,0107 \\ 0,8436 & 0,1153 & 0,0290 & 0,0121 \\ 0,8809 & 0,0883 & 0,0224 & 0,0084 \\ 0,9038 & 0,0614 & 0,0280 & 0,0069\end{array}$

The reference child is defined as having parents with some secondary education, eldest parent age 40, local unemployment equal to the national rate in 1993.

\subsection{Parents' Education and the Probability of Persistent Poverty}

Tables 7-9 present the probability of experiencing persistent poverty in none, one or up to three periods based on parental educational levels for children in Denmark, Norway and Sweden, respectively. While parents' education plays a significant role in the probability of poverty for native children as well as for immigrant children, the favorable effect of higher levels of parental education is much more pronounced for immigrant children. Immigrants with low levels of education are also much more likely to experience persistent poverty in Denmark and Norway than in Sweden. 
Table 7. Estimated Risk of Multiple Periods of Persistent Child Poverty for Selected Ethnic Groups by Parents’ Education. Denmark.

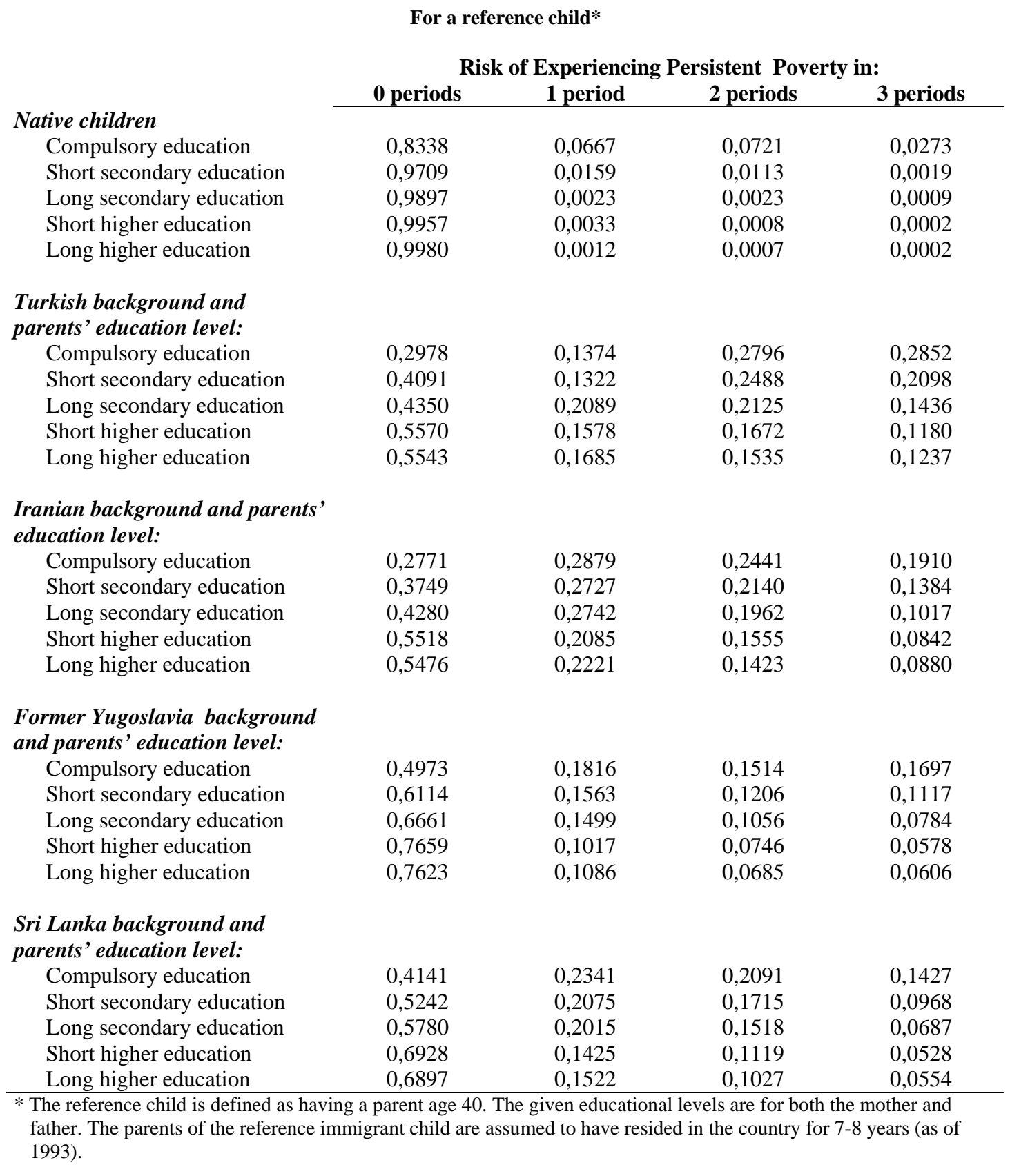


Table 8. Estimated Risk of Multiple Periods of Persistent Child Poverty for Selected Ethnic Groups by Parents’ Education. Norway.

For a reference child*

\section{Native children}

Compulsory education

Short secondary education

Long secondary education

Short higher education

Long higher education

Turkish background and

parents' education level:

Compulsory education

Short secondary education

Long secondary education

Short higher education

Long higher education

\begin{tabular}{cccc}
\multicolumn{5}{c}{ Risk of Experiencing Chronic Poverty in: } \\
0 periods & $\mathbf{1}$ period & 2 periods & 3 periods \\
\hline & & & \\
0,8735 & 0,0796 & 0,0325 & 0,0144 \\
0,9477 & 0,0367 & 0,0117 & 0,0039 \\
0,9758 & 0,0178 & 0,0049 & 0,0016 \\
0,9906 & 0,0078 & 0,0014 & 0,0003 \\
0,9808 & 0,0156 & 0,0031 & 0,0005
\end{tabular}

Iranian background and parents' education level:

Compulsory education

Short secondary education

Long secondary education

Short higher education

Long higher education

$\begin{array}{llll}0,2493 & 0,2267 & 0,1993 & 0,3246 \\ 0,4194 & 0,2568 & 0,1611 & 0,1628 \\ 0,4818 & 0,2414 & 0,1447 & 0,1320 \\ 0,6723 & 0,1242 & 0,0930 & 0,1105 \\ 0,5585 & 0,2096 & 0,0953 & 0,1366\end{array}$

Chilean background and parents' education level:

Compulsory education Short secondary education

Long secondary education

Short higher education

$\begin{array}{llll}0,3408 & 0,1991 & 0,1750 & 0,2850 \\ 0,5293 & 0,2082 & 0,1306 & 0,1320 \\ 0,5915 & 0,1904 & 0,1141 & 0,1041 \\ 0,7615 & 0,0903 & 0,0677 & 0,0804 \\ 0,6632 & 0,1599 & 0,0727 & 0,1042\end{array}$

Long higher education

$\begin{array}{llll}0,3422 & 0,1987 & 0,1747 & 0,2844 \\ 0,5309 & 0,2075 & 0,1301 & 0,1315 \\ 0,5930 & 0,1897 & 0,1137 & 0,1037 \\ 0,7627 & 0,0899 & 0,0674 & 0,0800 \\ 0,6646 & 0,1592 & 0,0724 & 0,1037\end{array}$

Somalian background and parents' education level:

Compulsory education

Short secondary education

Long secondary education

$\begin{array}{llll}0,2966 & 0,2124 & 0,1868 & 0,3041 \\ 0,4784 & 0,2307 & 0,1447 & 0,1462 \\ 0,5415 & 0,2136 & 0,1281 & 0,1168 \\ 0,7226 & 0,1051 & 0,0788 & 0,0936 \\ 0,6163 & 0,1822 & 0,0829 & 0,1187\end{array}$

Long higher education

* The reference child is defined as having a parent age 40. Local unemployment is set equal to the national rate in 1993.

The given educational levels are for both the mother and father. The parents of the reference immigrant child are assumed to have resided in the country for 7-8 years (as of 1993). 
Table 9. Estimated Risk of Multiple Periods of Persistent Child Poverty for Selected Ethnic Groups by Parents' Education. Sweden.

For a reference child*

\section{Native children}

Compulsory education

Short secondary education

Long secondary education

Short higher education

Long higher education

\begin{tabular}{cccc}
\multicolumn{5}{c}{ Risk of Experiencing Chronic Poverty in: } \\
0 periods & 1 period & 2 periods & 3 periods \\
\hline & & & \\
0,8828 & 0,0675 & 0,0281 & 0,0215 \\
0,9469 & 0,0316 & 0,0123 & 0,0091 \\
0,9511 & 0,0299 & 0,0121 & 0,0069 \\
0,9788 & 0,0144 & 0,0042 & 0,0026 \\
0,9923 & 0,0062 & 0,0013 & 0,0003
\end{tabular}

Turkish background and parents' education level:

Compulsory education Short secondary education Long secondary education Short higher education Long higher education

$\begin{array}{llll}0,5799 & 0,1816 & 0,1343 & 0,1042 \\ 0,5913 & 0,1731 & 0,1550 & 0,0807 \\ 0,6328 & 0,1822 & 0,1146 & 0,0704 \\ 0,6909 & 0,1210 & 0,1487 & 0,0395 \\ 0,7836 & 0,0825 & 0,0904 & 0,0435\end{array}$

Iranian background and parents' education level:

Compulsory education

Short secondary education

Long secondary education

Short higher education

Long higher education

\section{Chilean background and} parents' education level:

Compulsory education

Short secondary education

Long secondary education

Short higher education

Long higher education

\section{Somalian background and} parents' education level:

Compulsory education

Short secondary education

Long secondary education

Short higher education

Long higher education

$\begin{array}{llll}0,7258 & 0,1508 & 0,0889 & 0,0346 \\ 0,7305 & 0,1419 & 0,1012 & 0,0264 \\ 0,7597 & 0,1452 & 0,0727 & 0,0224 \\ 0,8032 & 0,0933 & 0,0914 & 0,0122 \\ 0,8729 & 0,0610 & 0,0532 & 0,0128\end{array}$

$\begin{array}{llll}0,8755 & 0,0939 & 0,0197 & 0,0110 \\ 0,8809 & 0,0883 & 0,0224 & 0,0084 \\ 0,8897 & 0,0877 & 0,0157 & 0,0069 \\ 0,9218 & 0,0553 & 0,0193 & 0,0037 \\ 0,9514 & 0,0343 & 0,0107 & 0,0037\end{array}$

* The reference child is defined as having a parent age 40. Local unemployment is set equal to the national rate in 1993.

The given educational levels are for both the mother and father. The parents of the reference immigrant child are assumed to have resided in the country for 7-8 years (as of 1993).

\section{Conclusions}

In this paper we have investigated immigrant and native child poverty in Denmark, Norway and Sweden from 1993 to 2001 using large sets of panel data. We have not only reported annual child 
poverty rates, but also rates of persistent child poverty as assessed based on income from a threeyear period. The study documents vastly higher rates of child poverty for immigrant children than for native children in each of the three Scandinavian countries. Furthermore, poverty among immigrant children, particularly children with backgrounds from middle- and low-income countries, is clearly of a much more prolonged or persistent nature than for native children. There is a clear decrease in child poverty relative to (parental) duration of residence. However, child poverty rates for immigrant children remain much higher than corresponding rates for native countries even for long durations of (parental) residence. The large differences in poverty rates for immigrants vs native children combined with increased immigration suggests that immigrant child poverty has and will continue to increase in relevance and play a major part in general trends for child poverty as a whole for these countries.

Our findings should be seen in light of insights from previous studies on the labour market situation of adult immigrants to the three countries. Many recent immigrants to Scandinavia from low and middle income countries face large difficulties in entering employment and earning a living. The reasons for this are likely to be many and not easily solved by one policy measure alone. Although many immigrants receive transfers from the public sector, neither employment nor the generous welfare states of the Scandinavian countries are sufficient for keeping a considerable subgroup of immigrant children out of poverty.

Although there are broad similarities in immigrant child poverty in the three countries, some notable cross-countries do exist. In particular, Sweden experienced a clear upward trend in both yearly and persistent poverty rates for immigrant children during the 1990s, most likely largely attributable to poor economic conditions and high unemployment in the country during the period. In contrast, improving labor market conditions in Norway were associated with a decline in children poverty rates for immigrant children in Norway. Poverty rates for immigrants children in Denmark remained largely stable at the highest level for the three countries through the period studied. Denmark also stands out as the country where immigrant child poverty seems to be of a much more prolonged nature compared with its Scandinavian neighbours.

The cross-country differences are somewhat surprising considering the fact that the countries share to a large extent the same institutional structure regarding the welfare state and the labour market. 
Part of the differences we find may reflect big differences in the arrival pattern of immigrants over time and the composition of immigrants according to ethnic background. Futhermore, even within ethnic groups represented in all three countries the distribution of relevant characteristics of can vary across the countires. Mirdal (1984), for example, points to the fact that the initial Turkish immigration to Denmark came directly from rural areas whereas initial Turkish immigrants to Sweden had a much higher proportion of political and religious refugees.

One obvious factor in explaining the big differences in child poverty between natives and MLIC immigrants is the significantly lower employment rates for immigrants and refugees. This has been well documented and analysed in the literature. ${ }^{9}$ This problem may be more pronounced in the Scandinavian than in most other rich OECD countries. OECD (2003) reports that among EU 15 countries, the employment gap between citizens and immigrant is largest in Denmark and Sweden with the gap having the same size in The Netherlands. In Norway, the gap is much smaller, i.e. around 2 percentage points compared with about 10 percentage points in Denmark and Sweden. There are most likely several reasons for the low employment rates among immigrants from low and middle income countries arriving to Scandinavia. Some explanations take characteristics of the immigrants themselves as point of departure; some immigrants, but far from the majority, have little education and the majority lack knowledge of the dominating language in the host countries. In general, education and skills may be difficult to transfer to the new social environment. Immigrants have less access to networks helpful for finding jobs (Behtoui, 2008). Other explanations can also focus on discrimination by potential employers, see for example Carlsson and Rooth (2007). The structure and organisation of the labour market can also play a part. In the Scandinavian labour markets wage floors are comparatively high. This may entail that recently arrived immigrant with few skills and, thus, low productivity will have difficulty finding employment. In some cases, immigrants may thus be forced into self-employment. Other suggested explanatory factors for the low employment among recent MLIC immigrants to the Scandinavian countries are that income related benefits in interplay with progressive income taxes create low incentives for gainful work for parents with many children. Finally, the public policy of integrating immigrants can have been less successful than expected.

\footnotetext{
${ }^{9}$ For surveys, see for example Pedersen and Smith (2002), Pedersen, (2005), Gustafsson, (2002) and Bengtsson et al (2005)
} 
The low employment of immigrants from low and middle income countries means that such persons are receiving transfers from the public sector in higher proportion than natives. However, social assistance and unemployment benefits are typically considerably lower than a full time wage. Furthermore, just as the labour market is adapted to the native population, the same may be the case for some public sector income compensating benefit programs, such as family cash benefits. 


\section{References}

Arts, W and Gelissen (2002) "Three Worlds of Welfare Capitalism or More? A State-of-theArt Report”, Journal of European Social Policy, 12, 137 - 58.

Atkinson, T., Cantillon, B, Marllier, E and Nolan, B. (2002) Social Indicators. The EU and Social Inclusion, Oxford: Oxford University Press.

Bhalla, A.S. and Mc Cormick, P. (2009) Poverty among Immigrant Children in Europe, Houndsmills: Palgrave, McMillan.

Barth, E., Bratsberg, B. and Raaum, O. (2004) "Identifying Earnings Assimilation of Immigrants under Changing Macroeconomic Conditions”, Scandinavian Journal of Economics, 106(1), 1-22.

Behtoui, A (2008) "Informal Recruitment Methods and Disadvantage of Immigrants in the Swedish Labour Market”, Journal of Ethnic and Migration Studies, 14, 445 - 471.

Blume, K., Gustafsson, B., Pedersen, P.J. and Verner, M. (2007) "At the Lower end of the Table Determinants of Poverty among Immigrants to Denmark and Sweden”, Journal of Ethnic and Migration Studies, 33, 373 - 396.

Bengtsson, T., Lundh, C and Scott, K. (2005) "From Boom to Bust: The Economic Integration of Immigrants in Postwar Sweden”, in Zimmermann, K. (Editor) European Migration: What do We Know?, Oxford: Oxford University Press.

Carlsson, M. and Rooth, D-O (2007) "Evidence of Discrimination in the Swedish Labor Market Using Experimental Data”, Labour Economics, 14, 716-729.

Chen, W-H and M. Corak. (2008). "Child Poverty and Changes in Child Poverty”, Demography, 45, $537-553$.

Chiswick; B.R., Lee, Y.L. and Miller, P.W. (2005) "Immigrant Earnings: A Longitudinal Analysis”, Review of Income and Wealth, 51(4), 485-503.

Corak, M., Fertig, M. and Tamm, M (2008) “A Portrait of Child Poverty in Germany”, Review of Income and Wealth, 54(4), 547-571.

Dumont, J.-C. and LeMaître,G. (2005) Counting Immigrants and Expatriates in OECD Countries: A New Perspective. Paris. OECD Social, Employment and Migration Working Papers 25.

Esping-Andersen, G. (1990) The Three Worlds of Welfare Capitalism, Cambridge: Policy Press.

Galloway, T., and Aaberge, R. (2005) "Assimilation Effects on Poverty among Immigrants in Norway”, Journal of Population Economics, 18, 691 - 718. 
Gustafsson, B. (2002) “Sweden's Recent Experience of International Migration - Issues and Studies", in Rotte, R. and Stein, P. (Eds) Migration Policy and the Economy: International Experiences, Neuried: ars et unitas.

Gustafsson, B. and P.J. Pedersen (eds.). 2000. Poverty and Low Income in the Nordic Countries. Ashgate. Aldershot.

Hammarstedt, M. And Shukur, G. (2007) "Immigrants' Relative Earnings in Sweden - A Quantile Regression Approach”, International Journal of Manpower, 28(6), 456-473.

Hansen, J. and Wahlberg, R. (2009) "Poverty and its Persistence: A Comparison of Natives and Immigrants in Sweden”, Review of Economics of the Husehold, 7, $105-132$.

Hussain, A. (2003) Bornefattigdom i danske kommuner 1984 - 2001. Copenhagen: Socialforskningsinstituttet and Save the Children Denmark.

Husted, L., Nielsen, H.S., Rosholm, M. and Smith, N. (2001) "Employment and Wage Assimilation of Male First Generation Immigrants in Denmark", International Journal of Manpower, 22, 39-68.

Iceland, J. (2000) "The Family/Couple/Household Unit of Measurement in Poverty Estimation”, Journal of Economic and Social Measurement, 26, 3-4: 253-265.

Lichter, D., Qian, Z and Crowley, M. (2005) "Child Poverty Among Racial Minorities and Immigrants: Explaining Trends and Differentials”, Social Science Quarterly, Supplement to vol 86, 1037 - 1059.

Longva, P. and Raaum, O. (2003) "Earnings Assimilation of Immigrants in Norway - A Reappraisal”, Journal of Population Economics, 16(1), 177-193.

Mirdal, G.M. (1984) "Stress and Distress in Migration: Problems and Resources of Turkish Women in Denmark”, International Migration Review, 18, 4, 984-1003.

OECD (2003). Employment Outlook. Paris.

Pedersen, P.J. \& Smith, N. (2002) “International Migration and Migraiton Policy in Denmark” in Rotte, R. and Stein, P. (Eds) Migration Policy and the Economy: International Experiences, Neuried: ars et unitas.

Pedersen, P.J.(2005) "Immigration in a High Unemployment Economy: The Recent Danish Experience" in Zimmermann, K. (Editor) European Migration: What do We Know?, Oxford: Oxford University Press.

Roseveare, D. and Jørgensen, M (2004) "Migration and Integration of Immigrants in Denmark. Economics Department Working Papers No. 368. OECD. Paris.

Roed, K. and Raaum, O. (2003) “Administrative Registers - Unexplored Reservoirs of Scientific Knowledge?”, Economic Journal, 113, F258-F281. 
Save the Children Sweden (2008) Barnfattigdom i Sverige 2007. Årsrapport. Stockholm

van Hook, H., Brown, S. and Kwenda, N. (2004) “ A Decomposition of Trends in Poverty among Children of Immigrants”, Demography, 41, 649-670.

Ytrehus, S. (2004) Fattige barn i Norge - Hvem er de og hvor bor de? Fafo - rapport 445. Oslo. 


\section{Appendix}

Table A.1 Child Poverty Rates in Norway, Sweden and Denmark by Immigration Category. 1993-2001. Percent.

\begin{tabular}{lrrrrrrrrr} 
& $\mathbf{1 9 9 3}$ & $\mathbf{1 9 9 4}$ & $\mathbf{1 9 9 5}$ & $\mathbf{1 9 9 6}$ & $\mathbf{1 9 9 7}$ & $\mathbf{1 9 9 8}$ & $\mathbf{1 9 9 9}$ & $\mathbf{2 0 0 0}$ & $\mathbf{2 0 0 1}$ \\
\hline Denmark & & & & & & & & & \\
\hline Native & 8,1 & 7,3 & 7,9 & 7,8 & 7,9 & 8,0 & 7,9 & 7,6 & 7,9 \\
HIC & 19,8 & 19,4 & 18,2 & 20,6 & 20,4 & 20,1 & 19,0 & 17,2 & 18,5 \\
MLIC & 56,5 & 51,9 & 53,6 & 58,3 & 57,5 & 57,4 & 56,3 & 53,2 & 53,6 \\
\hline All & 11,2 & 10,3 & 11,0 & 11,5 & 12,1 & 12,4 & 12,3 & 11,9 & 12,5 \\
\hline & & & & & & & & & \\
Norway & & & & & & & & & 7,0 \\
\hline Native & 8,2 & 7,6 & 7,8 & 7,8 & 7,9 & 7,5 & 7,0 & 7,7 \\
HIC & 14,2 & 13,3 & 13,8 & 13,6 & 13,3 & 13,2 & 12,1 & 12,7 & 13,6 \\
MLIC & 49,9 & 50,3 & 47,3 & 45,1 & 43,7 & 40,2 & 36,8 & 38,1 & 39,0 \\
\hline All & 9,9 & 9,5 & 9,7 & 9,7 & 9,8 & 9,4 & 8,8 & 9,1 & 9,8 \\
\hline
\end{tabular}

\begin{tabular}{|c|c|c|c|c|c|c|c|c|c|}
\hline weden & & & & & & & & & \\
\hline Native & 6,7 & 6,2 & 6,8 & 8,3 & 8,4 & 8,1 & 8,2 & 7,9 & 7,8 \\
\hline HIC & 12,1 & 12,7 & 14,5 & 16,0 & 16,6 & 19,0 & 18,9 & 19,6 & 20,0 \\
\hline MLIC & 32,0 & 35,4 & 40,3 & 42,1 & 42,3 & 46,2 & 48,6 & 47,3 & 46,3 \\
\hline All & 9,7 & 9,6 & 10,7 & 12,5 & 13,2 & 13,7 & 14,5 & 14,5 & 14,7 \\
\hline
\end{tabular}

Native children have two native-born parents. MLIC refers to children with background from a Middle- or Low-Income Country. HIC refers to children with background from a High-Income Country. See Section 3 for further details on these definitions.

Table A.2 Child Poverty Entry Rates by Immigration Category. 1993-2001. Percent

\begin{tabular}{lrrrrrrrr}
\hline & $\mathbf{1 9 9 4}$ & $\mathbf{1 9 9 5}$ & $\mathbf{1 9 9 6}$ & $\mathbf{1 9 9 7}$ & $\mathbf{1 9 9 8}$ & $\mathbf{1 9 9 9}$ & $\mathbf{2 0 0 0}$ & $\mathbf{2 0 0 1}$ \\
\hline Denmark & & & & & & & & \\
Natives & 2,0 & 2,3 & 2,1 & 2,2 & 2,4 & 2,2 & 2,3 & 2,5 \\
HIC & 3,7 & 5,5 & 4,0 & 4,3 & 4,0 & 3,7 & 5,2 & 4,0 \\
MLIC & 13,2 & 16,9 & 17,7 & 15,8 & 15,7 & 13,9 & 12,1 & 13,3 \\
& & & & & & & & \\
Norway & & & & & & & & \\
Natives & 3,1 & 3,5 & 3,6 & 3,6 & 3,4 & 3,1 & 3,4 & 3,9 \\
HIC & 4,8 & 5,7 & 5,6 & 5,5 & 5,4 & 4,7 & 5,7 & 6,5 \\
MLIC & 18,7 & 20,4 & 20,2 & 19,2 & 15,8 & 13,5 & 14,2 & 16,0 \\
& & & & & & & & \\
Sweden & & & & & & & & \\
Natives & 1,9 & 2,6 & 3,1 & 2,9 & 2,3 & 2,9 & 2,0 & 2,4 \\
HIC & 4,8 & 5,3 & 5,6 & 4,6 & 5,0 & 5,3 & 3,9 & 5,0 \\
MLIC & 13,1 & 16,4 & 15,6 & 13,0 & 13,8 & 16,0 & 12,2 & 13,5 \\
\hline
\end{tabular}

Native children have two native-born parents. MLIC refers to children with background from a Middle- or Low-Income Country. HIC refers to children with background from a High-Income Country. See Section 3 for further details on these definitions. 
Table A.3 Child Poverty Exit Rates by Immigration Category. 1993-2001. Percent

\begin{tabular}{|c|c|c|c|c|c|c|c|c|}
\hline & 1994 & 1995 & 1996 & 1997 & 1998 & 1999 & 2000 & 2001 \\
\hline \multicolumn{9}{|l|}{ Denmark } \\
\hline Natives & 46,3 & 38,9 & 40,2 & 37,7 & 40,7 & 39,2 & 43,6 & 39,5 \\
\hline HIC & 40,8 & 32,4 & 41,1 & 36,9 & 34,4 & 35,4 & 32,4 & 41,1 \\
\hline MLIC & 25,1 & 18,2 & 19,6 & 19,5 & 18,7 & 18,7 & 21,0 & 21,3 \\
\hline \multicolumn{9}{|l|}{ Norway } \\
\hline Natives & 42,6 & 41,0 & 44,7 & 42,6 & 43,8 & 44,3 & 42,9 & 40,5 \\
\hline HIC & 37,1 & 35,1 & 38,6 & 36,8 & 37,2 & 40,5 & 35,9 & 34,7 \\
\hline MLIC & 22,5 & 25,0 & 26,4 & 25,3 & 26,7 & 28,8 & 27,1 & 24,1 \\
\hline \multicolumn{9}{|l|}{ Sweden } \\
\hline Natives & 37,6 & 33,4 & 30,7 & 31,1 & 41,5 & 36,5 & 43,6 & 39,6 \\
\hline HIC & 35,7 & 31,3 & 30,7 & 30,2 & 36,3 & 30,8 & 33,8 & 31,8 \\
\hline MLIC & 25,0 & 21,2 & 20,9 & 22,0 & 29,0 & 17,8 & 21,5 & 21,6 \\
\hline
\end{tabular}


Table A.4. Multinomial Logit estimating number of 3- year periods in persistent poverty. Pesistent poverty in 0 periods is the comparison group. Children from Middle- and Low-Income countries. Denmark.

\begin{tabular}{|c|c|c|c|c|c|c|c|c|c|}
\hline & \multicolumn{3}{|c|}{ Chronic Poverty in 1 Period } & \multicolumn{3}{|c|}{ Chronic Poverty in 2 Periods } & \multicolumn{3}{|c|}{ Chronic Poverty in 3 Periods } \\
\hline & Coeff. & Std.Err & $\mathrm{P}>|\mathrm{z}|$ & Coeff & Std.Err. & $\mathrm{P}>|\mathrm{z}|$ & Coeff. & Std.Err. & $\mathrm{P}>\mid \mathrm{z}$ \\
\hline No Father & 0,6275 & 0,0653 & 0,000 & 0,7304 & 0,0649 & 0,000 & 0,9989 & 0,0597 & 0,000 \\
\hline Father no education information & 0,1296 & 0,0537 & 0,016 & 0,0148 & 0,0536 & 0,783 & $-0,1449$ & 0,0511 & 0,005 \\
\hline Father short secondary education & $-0,2976$ & 0,0456 & 0,000 & $-0,3589$ & 0,0447 & 0,000 & $-0,5554$ & 0,0415 & 0,000 \\
\hline Father long secondary education & $-0,4156$ & 0,0871 & 0,000 & $-0,3443$ & 0,0823 & 0,000 & $-0,6857$ & 0,0801 & 0,000 \\
\hline Father short higher education & $-0,7776$ & 0,0831 & 0,000 & $-0,9030$ & 0,0822 & 0,000 & $-1,1441$ & 0,0745 & 0,000 \\
\hline Father long higher education & $-0,5484$ & 0,0910 & 0,000 & $-0,8674$ & 0,0957 & 0,000 & $-0,9730$ & 0,0875 & 0,000 \\
\hline No Mother & 0,2695 & 0,1853 & 0,146 & 0,1373 & 0,1907 & 0,471 & 0,2658 & 0,1787 & 0,137 \\
\hline Mother no education information & $-0,4060$ & 0,0419 & 0,000 & $-0,5269$ & 0,0417 & 0,000 & $-0,6938$ & 0,0391 & 0,000 \\
\hline Mother short secondary education & $-0,0589$ & 0,0481 & 0,220 & $-0,0751$ & 0,0470 & 0,110 & $-0,0689$ & 0,0436 & 0,114 \\
\hline Mother long secondary education & $-0,0680$ & 0,1164 & 0,559 & $-0,3090$ & 0,1227 & 0,012 & $-0,3792$ & 0,1136 & 0,001 \\
\hline Mother short higher education & $-0,2339$ & 0,0993 & 0,019 & $-0,2370$ & 0,0984 & 0,016 & $-0,3644$ & 0,0959 & 0,000 \\
\hline Mother long higher education & $-0,3923$ & 0,1504 & 0,009 & $-0,3532$ & 0,1465 & 0,016 & $-0,4836$ & 0,1378 & 0,000 \\
\hline Parent's age in $1993^{10}$ & 0,0103 & 0,0028 & 0,000 & 0,0200 & 0,0026 & 0,000 & 0,0396 & 0,0025 & 0,000 \\
\hline Child 0-2 of age in 1993 & 0,1359 & 0,0381 & 0,000 & 0,1800 & 0,0378 & 0,000 & 0,3215 & 0,0359 & 0,000 \\
\hline More than 2 children & 0,8584 & 0,0490 & 0,000 & 1,3086 & 0,0459 & 0,000 & 2,4689 & 0,0416 & 0,000 \\
\hline More siblings during the period & 0,1963 & 0,0556 & 0,000 & 0,4995 & 0,0529 & 0,000 & 0,9546 & 0,0487 & 0,000 \\
\hline Turkey & $-0,3549$ & 0,1334 & 0,008 & $-0,6718$ & 0,1227 & 0,000 & $-1,1841$ & 0,1168 & 0,000 \\
\hline Former Yugoslavia & $-1,1124$ & 0,1432 & 0,000 & $-1,7975$ & 0,1362 & 0,000 & $-2,2158$ & 0,1292 & 0,000 \\
\hline Lebanon & 0,0465 & 0,1522 & 0,760 & 0,1144 & 0,1388 & 0,410 & 0,5332 & 0,1303 & 0,000 \\
\hline Vietnam & $-1,8586$ & 0,8398 & 0,027 & $-2,0451$ & 0,5667 & 0,000 & $-36,9868$ & 0,4034 & 0,000 \\
\hline Iran & $-0,0665$ & 0,1459 & 0,648 & $-0,7353$ & 0,1392 & 0,000 & $-1,5124$ & 0,1393 & 0,000 \\
\hline Pakistan & $-0,2620$ & 0,1449 & 0,071 & $-0,4527$ & 0,1328 & 0,001 & $-0,4791$ & 0,1246 & 0,000 \\
\hline Sri Lanka & $-0,6751$ & 0,1503 & 0,000 & $-1,2919$ & 0,1419 & 0,000 & $-2,2058$ & 0,1417 & 0,000 \\
\hline Other ethnic background & $-0,9560$ & 0,1288 & 0,000 & $-1,5071$ & 0,1184 & 0,000 & $-1,7816$ & 0,1120 & 0,000 \\
\hline Parents in country 3-4 years & $-0,4447$ & 0,0745 & 0,000 & $-0,5064$ & 0,0735 & 0,000 & $-0,5047$ & 0,0687 & 0,000 \\
\hline Parents in country 5-6 years & $-0,8018$ & 0,0723 & 0,000 & $-0,8736$ & 0,0713 & 0,000 & $-0,9154$ & 0,0671 & 0,000 \\
\hline Parents in country $7-8$ years & $-0,8304$ & 0,0779 & 0,000 & $-0,8733$ & 0,0761 & 0,000 & $-0,8767$ & 0,0714 & 0,000 \\
\hline Parents in country more than 8 years & $-1,0781$ & 0,0614 & 0,000 & $-1,2063$ & 0,0610 & 0,000 & $-1,2349$ & 0,0573 & 0,000 \\
\hline Constant & 0,5232 & 0,1703 & 0,002 & 0,6818 & 0,1627 & 0,000 & 0,4333 & 0,1534 & 0,005 \\
\hline
\end{tabular}

\footnotetext{
${ }^{10}$ In families with two parents, this is the age of the eldest parent.
} 
Table A.5. Multinomial Logit estimating number of 3-year periods in persistent poverty. Persistent poverty in 0 periods is the comparison group. Natives, Denmark

\begin{tabular}{|c|c|c|c|c|c|c|c|c|c|}
\hline & \multicolumn{3}{|c|}{ Chronic Poverty in 1 Period } & \multicolumn{3}{|c|}{ Chronic Poverty in 2 Periods } & \multicolumn{3}{|c|}{ Chronic Poverty in 3 Periods } \\
\hline & Coeff. & Std.Err. & $\mathrm{P}>|\mathrm{z}|$ & Coeff & Std.Err. & $\mathrm{P}>|\mathrm{z}|$ & Coeff. & Std.Err. & $\mathrm{P}>\mid \mathrm{z}$ \\
\hline No Father & 1,5203 & 0,0845 & 0,000 & 1,2671 & 0,1079 & 0,000 & 2,1594 & 0,1390 & 0,000 \\
\hline Father no education information & $-0,1703$ & 0,0795 & 0,032 & $-0,6143$ & 0,1042 & 0,000 & $-0,2713$ & 0,1326 & 0,041 \\
\hline Father short secondary education & $-0,7009$ & 0,0335 & 0,000 & $-0,7609$ & 0,0451 & 0,000 & $-1,1667$ & 0,0517 & 0,000 \\
\hline Father long secondary education & $-1,1667$ & 0,0950 & 0,000 & $-1,2759$ & 0,1352 & 0,000 & $-1,6641$ & 0,1639 & 0,000 \\
\hline Father short higher education & $-1,5681$ & 0,0771 & 0,000 & $-2,5162$ & 0.1586 & 0,000 & $-2,3981$ & 0,1532 & 0,000 \\
\hline Father long higher education & $-1,6977$ & 0,0958 & 0,000 & $-2,0273$ & 0,1471 & 0,000 & $-2,3285$ & 0,1663 & 0,000 \\
\hline No Mother & 0,9070 & 0,1656 & 0,000 & 0,1580 & 0,2323 & 0,496 & 0,4037 & 0,3479 & 0,246 \\
\hline Mother no education information & $-0,1725$ & 0,0788 & 0,029 & $-0,7849$ & 0,1003 & 0,000 & $-0,0883$ & 0,1323 & 0,504 \\
\hline Mother short secondary education & $-0,8882$ & 0,0393 & 0,000 & $-1,2448$ & 0,0525 & 0,000 & $-1,6540$ & 0,0697 & 0,000 \\
\hline Mother long secondary education & $-1,2556$ & 0,1236 & 0,000 & $-2,3297$ & 0,2462 & 0,000 & $-1,9242$ & 0,2320 & 0,000 \\
\hline Mother short higher education & $-1,6181$ & 0,0697 & 0,000 & $-2,1233$ & 0,1027 & 0,000 & $-2,7014$ & 0,1485 & 0,000 \\
\hline Mother long higher education & $-2,5281$ & 0,2385 & 0,000 & $-2,7716$ & 0,3184 & 0,000 & $-2,9442$ & 0,3848 & 0,000 \\
\hline Parent's age in $1993^{11}$ & $-0,0200$ & 0,0026 & 0,000 & $-0,0052$ & 0,0034 & 0,126 & 0,0136 & 0,0039 & 0,000 \\
\hline Child 0-2 of age in 1993 & 0,4378 & 0,0279 & 0,000 & 0,4384 & 0,0375 & 0,000 & 0,7743 & 0,0461 & 0,000 \\
\hline More than 2 children & 1,4126 & 0,0769 & 0,000 & 1,9225 & 0.0832 & 0,000 & 3,2148 & 0,0658 & 0,000 \\
\hline More siblings during the period & 0,1636 & 0,0386 & 0,000 & $-0,0831$ & 0.0576 & 0,149 & 0,0844 & 0,0632 & 0,182 \\
\hline Constant & $-1,7253$ & 0,1239 & 0,000 & $-2,2393$ & 0,1589 & 0,000 & $-3,9615$ & 0,2008 & 0,000 \\
\hline
\end{tabular}

\footnotetext{
${ }^{11}$ In families with two parents, this is the age of the eldest parent
} 
Table A.6. Multinomial Logit estimating number of 3- year periods in persistent poverty. Pesistent poverty in 0 periods is the comparison group. Children from Middle- and Low-Income Countries. Norway.

\begin{tabular}{|c|c|c|c|c|c|c|c|c|c|}
\hline & \multicolumn{3}{|c|}{ Chronic Poverty in 1 Period } & \multicolumn{3}{|c|}{ Chronic Poverty in 2 Periods } & \multicolumn{3}{|c|}{ Chronic Poverty in 3 Periods } \\
\hline & Coeff. & Std.Err. & $\mathbf{P}>|\mathbf{z}| \mid$ & Coeff. & Std.Err. & $\mathbf{P}>|\mathbf{z}| \mid$ & Coeff. & Std.Err. & $\mathbf{P}>|\mathbf{z}|$ \\
\hline No father & $-0,3477$ & 0,0565 & 0,0000 & $-0,6355$ & 0,0631 & 0,0000 & $-1,1170$ & 0,0700 & 0,0000 \\
\hline Father No education infomation & 0,5917 & 0,3265 & 0,0700 & 0,8507 & 0,3268 & 0,0090 & 0,3264 & 0,3471 & 0,3470 \\
\hline Father Secondary education le 2 years & $-0,0166$ & 0,0535 & 0,7570 & $-0,0883$ & 0,0574 & 0,1240 & $-0,1484$ & 0,0568 & 0,0090 \\
\hline Father Secondary education ge 3 years & $-0,1308$ & 0,0624 & 0,0360 & $-0,2551$ & 0,0702 & 0,0000 & $-0,4359$ & 0,0723 & 0,0000 \\
\hline Father University lt 3 years & $-0,3964$ & 0,0711 & 0,0000 & $-0,3425$ & 0,0780 & 0,0000 & $-0,6595$ & 0,0835 & 0,0000 \\
\hline Father University ge 3 years & $-0,8117$ & 0,1297 & 0,0000 & $-0,7531$ & 0,1457 & 0,0000 & $-0,8275$ & 0,1451 & 0,0000 \\
\hline No Mother & $-0,0989$ & 0,1424 & 0,4870 & $-0,0164$ & 0,1474 & 0,9110 & $-0,2103$ & 0,1563 & 0,1790 \\
\hline Mother No education infomation & $-0,2658$ & 0,4132 & 0,5200 & 0,0128 & 0,4095 & 0,9750 & 0,3045 & 0,3953 & 0,4410 \\
\hline Mother Secondary education le 2 years & $-0,2648$ & 0,0605 & 0,0000 & $-0,4783$ & 0,0685 & 0,0000 & $-0,7743$ & 0,0745 & 0,0000 \\
\hline Mother Secondary education ge 3 years & $-0,1997$ & 0,0657 & 0,0020 & $-0,6368$ & 0,0801 & 0,0000 & $-0,8993$ & 0,0878 & 0,0000 \\
\hline Mother University lt 3 years & $-0,7823$ & 0,0802 & 0,0000 & $-1,0008$ & 0,0922 & 0,0000 & $-1,2418$ & 0,0985 & 0,0000 \\
\hline Mother University ge 3 years & $-0,7859$ & 0,1658 & 0,0000 & $-1,5276$ & 0,2388 & 0,0000 & $-1,4622$ & 0,2268 & 0,0000 \\
\hline Parent's age in 1993 & 0,0126 & 0,0029 & 0,0000 & 0,0174 & 0,0031 & 0,0000 & 0,0313 & 0,0031 & 0,0000 \\
\hline Child 0-3 years of age in 1993 & 0,1679 & 0,0383 & 0,0000 & 0,1820 & 0,0416 & 0,0000 & 0,2730 & 0,0422 & 0,0000 \\
\hline More than 2 children & 0,6230 & 0,0411 & 0,0000 & 1,1295 & 0,0441 & 0,0000 & 1,6371 & 0,0453 & 0,0000 \\
\hline More siblings during the period & 0,1823 & 0,0407 & 0,0000 & 0,5138 & 0,0442 & 0,0000 & 0,7385 & 0,0451 & 0,0000 \\
\hline Local unemployment rate in 1993 & 0,0808 & 0,0286 & 0,0050 & 0,3599 & 0,0339 & 0,0000 & 0,3254 & 0,0349 & 0,0000 \\
\hline Serbia & $-0,2108$ & 0,1117 & 0,0590 & $-0,3592$ & 0,1160 & 0,0020 & $-0,4420$ & 0,1176 & 0,0000 \\
\hline Marokko & 0,2917 & 0,1151 & 0,0110 & 0,3073 & 0,1144 & 0,0070 & 0,0150 & 0,1145 & 0,8960 \\
\hline Somalia & $-0,2390$ & 0,1256 & 0,0570 & $-0,5684$ & 0,1337 & 0,0000 & $-0,7368$ & 0,1386 & 0,0000 \\
\hline Sri Lanka & $-1,0095$ & 0,1009 & 0,0000 & $-1,6448$ & 0,1211 & 0,0000 & $-2,2421$ & 0,1434 & 0,0000 \\
\hline India & $-0,8406$ & 0,1098 & 0,0000 & $-1,0757$ & 0,1231 & 0,0000 & $-1,4073$ & 0,1343 & 0,0000 \\
\hline Iran & $-0,4427$ & 0,0995 & 0,0000 & $-0,6646$ & 0,1075 & 0,0000 & $-1,1019$ & 0,1200 & 0,0000 \\
\hline Pakistan & 0,5465 & 0,0768 & 0,0000 & 0,5244 & 0,0780 & 0,0000 & 0,7511 & 0,0755 & 0,0000 \\
\hline Vietnam & $-0,1513$ & 0,0786 & 0,0540 & $-0,5274$ & 0,0836 & 0,0000 & $-0,9422$ & 0,0867 & 0,0000 \\
\hline Chile & $-0,4489$ & 0,0979 & 0,0000 & $-1,0238$ & 0,1147 & 0,0000 & $-1,3826$ & 0,1315 & 0,0000 \\
\hline Other ethnic background & $-0,5617$ & 0,0775 & 0,0000 & $-0,6956$ & 0,0810 & 0,0000 & $-0,6874$ & 0,0806 & 0,0000 \\
\hline Parents in the country 3-4 years & $-0,4420$ & 0,0820 & 0,0000 & $-0,2823$ & 0,0863 & 0,0010 & $-0,2025$ & 0,0907 & 0,0260 \\
\hline Parents in the country 5-6 years & $-0,6587$ & 0,0759 & 0,0000 & $-0,6062$ & 0,0812 & 0,0000 & $-0,5698$ & 0,0854 & 0,0000 \\
\hline Parents in the country 7-8 years & $-0,8809$ & 0,0910 & 0,0000 & $-1,1074$ & 0,1028 & 0,0000 & $-0,6316$ & 0,1027 & 0,0000 \\
\hline Parents in the country 9 or more years & $-1,4925$ & 0,0774 & 0,0000 & $-1,5638$ & 0,0832 & 0,0000 & $-1,4131$ & 0,0860 & 0,0000 \\
\hline Constant & $-0,2413$ & 0,1807 & 0,1820 & $-1,8457$ & 0,2046 & 0,0000 & $-2,4677$ & 0,2097 & 0,0000 \\
\hline
\end{tabular}


Table A.7. Multinomial Logit estimating number of 3-year periods in persistent poverty. Persistent poverty in 0 periods is the comparison group. .Native born parents. Norway.

\begin{tabular}{|c|c|c|c|c|c|c|c|c|c|}
\hline & \multicolumn{3}{|c|}{ Chronic Poverty in 1 Period } & \multicolumn{3}{|c|}{ Chronic Poverty in 2 Periods } & \multicolumn{3}{|c|}{ Chronic Poverty in 3 Periods } \\
\hline & Coeff. & Std.Err. & $\mathbf{P}>|\mathbf{z}| \mid$ & Coeff. & Std.Err. & $\mathbf{P}>|\mathbf{z}| \mid$ & Coeff. & Std.Err. & $\mathbf{P}>|\mathbf{z}|$ \\
\hline No father & 0,0895 & 0,0183 & 0,0000 & 0,0674 & 0,0254 & 0,0080 & 0,0630 & 0,0327 & 0,0540 \\
\hline Father No education infomation & 0,0718 & 0,1913 & 0,7070 & 0,1084 & 0,2633 & 0,6800 & $-1,6827$ & 0,7175 & 0,0190 \\
\hline Father Secondary education le 2 years & $-0,2515$ & 0,0143 & 0,0000 & $-0,2703$ & 0,0199 & 0,0000 & $-0,3175$ & 0,0256 & 0,0000 \\
\hline Father Secondary education ge 3 years & $-0,5797$ & 0,0154 & 0,0000 & $-0,7367$ & 0,0223 & 0,0000 & $-0,8920$ & 0,0298 & 0,0000 \\
\hline Father University lt 3 years & $-1,0285$ & 0,0218 & 0,0000 & $-1,2057$ & 0,0329 & 0,0000 & $-1,4012$ & 0,0455 & 0,0000 \\
\hline Father University ge 3 years & $-1,3484$ & 0,0380 & 0,0000 & $-1,8358$ & 0,0679 & 0,0000 & $-2,2754$ & 0,1068 & 0,0000 \\
\hline No Mother & $-0,1948$ & 0,0410 & 0,0000 & $-0,3422$ & 0,0602 & 0,0000 & $-0,5463$ & 0,0855 & 0,0000 \\
\hline Mother No education infomation & $-0,9764$ & 0,3023 & 0,0010 & $-1,6782$ & 0,5875 & 0,0040 & $-0,0159$ & 0,3911 & 0,9680 \\
\hline Mother Secondary education le 2 years & $-0,2748$ & 0,0142 & 0,0000 & $-0,3668$ & 0,0196 & 0,0000 & $-0,5069$ & 0,0251 & 0,0000 \\
\hline Mother Secondary education ge 3 years & $-0,5797$ & 0,0166 & 0,0000 & $-0,8008$ & 0,0242 & 0,0000 & $-0,9345$ & 0,0320 & 0,0000 \\
\hline Mother University lt 3 years & $-1,1032$ & 0,0218 & 0,0000 & $-1,4630$ & 0,0338 & 0,0000 & $-1,6745$ & 0,0464 & 0,0000 \\
\hline Mother University ge 3 years & $-1,5526$ & 0,0670 & 0,0000 & $-2,1273$ & 0,1280 & 0,0000 & $-2,9357$ & 0,2534 & 0,0000 \\
\hline Parent's age in 1993 & $-0,0271$ & 0,0009 & 0,0000 & $-0,0010$ & 0,0013 & 0,4170 & 0,0151 & 0,0017 & 0,0000 \\
\hline Child 0-3 years of age in 1993 & 0,2197 & 0,0098 & 0,0000 & 0,4030 & 0,0143 & 0,0000 & 0,6212 & 0,0195 & 0,0000 \\
\hline More than 2 children & 0,8963 & 0,0106 & 0,0000 & 1,2944 & 0,0150 & 0,0000 & 1,7549 & 0,0199 & 0,0000 \\
\hline More siblings during the period & 0,4456 & 0,0103 & 0,0000 & 0,7707 & 0,0151 & 0,0000 & 0,9664 & 0,0203 & 0,0000 \\
\hline Local unemployment rate in 1993 & 0,0631 & 0,0057 & 0,0000 & 0,1221 & 0,0084 & 0,0000 & 0,1472 & 0,0112 & 0,0000 \\
\hline Constant & $-1,5793$ & 0,0456 & 0,0000 & $-3,7646$ & 0,0662 & 0,0000 & $-5,3262$ & 0,0883 & 0,0000 \\
\hline
\end{tabular}


Table A.8. Multinomial Logit estimating number of 3- year periods in persistent poverty. Pesistent poverty in 0 periods is the comparison group.

Children from Middle- and Low-Income Countries. Sweden.

\begin{tabular}{|c|c|c|c|c|c|c|c|c|c|c|c|c|}
\hline & 1 & Coef. & Std. & $\mathbf{P}>|\mathbf{z}|$ & 2 & Coef. & Std. & $\mathbf{P}>|\mathbf{z}|$ & 3 & Coef. & Std. & $\mathbf{P}>|\mathbf{z}|$ \\
\hline Parent's age in 1993 & & 0,0062 & 0,0128 & 0,6300 & & $-0,0469$ & 0,0139 & 0,0010 & & $-0,0314$ & 0,0137 & 0,0220 \\
\hline \multicolumn{13}{|l|}{ Reference: Turkey } \\
\hline Eastern Europé and Russia & & $-1,2312$ & 0,4026 & 0,0020 & & $-1,6056$ & 0,3978 & 0,0000 & & $-1,8634$ & 0,4429 & 0,0000 \\
\hline SubSahara and Etiopia & & $-1,1897$ & 0,3888 & 0,0020 & & $-1,2869$ & 0,3616 & 0,0000 & & $-1,7701$ & 0,3738 & 0,0000 \\
\hline Arabcountries & & $-0,1387$ & 0,3183 & 0,6630 & & $-0,3235$ & 0,2934 & 0,2700 & & $-0,1430$ & 0,2803 & 0,6100 \\
\hline Chile & & $-1,0719$ & 0,3658 & 0,0030 & & $-2,3316$ & 0,4522 & 0,0000 & & $-2,6636$ & 0,4787 & 0,0000 \\
\hline South America & & $-1,2759$ & 0,4838 & 0,0080 & & $-2,1972$ & 0,5555 & 0,0000 & & $-2,3283$ & 0,5704 & 0,0000 \\
\hline Iraq & & $-0,6962$ & 0,3639 & 0,0560 & & $-0,6742$ & 0,3316 & 0,0420 & & $-0,8464$ & 0,3269 & 0,0100 \\
\hline Iran & & $-0,4100$ & 0,3329 & 0,2180 & & $-0,6376$ & 0,3197 & 0,0460 & & $-1,3284$ & 0,3458 & 0,0000 \\
\hline Somalia & & $-0,5933$ & 0,4838 & 0,2200 & & $-0,8752$ & 0,4688 & 0,0620 & & $-0,4953$ & 0,4261 & 0,2450 \\
\hline Asia & & $-0,5793$ & 0,3356 & 0,0840 & & $-1,2747$ & 0,3322 & 0,0000 & & $-0,8404$ & 0,3057 & 0,0060 \\
\hline Single parent in 1993 & & $-0,4298$ & 0,1971 & 0,0290 & & $-1,1911$ & 0,2437 & 0,0000 & & $-1,4489$ & 0,2592 & 0,0000 \\
\hline More than 2 children & & 0,3786 & 0,1685 & 0,0250 & & 0,7822 & 0,1760 & 0,0000 & & 1,3986 & 0,1857 & 0,0000 \\
\hline Child 0-3 years of age in 1993 & & 0,3570 & 0,1604 & 0,0260 & & 0,5733 & 0,1632 & 0,0000 & & 1,0060 & 0,1700 & 0,0000 \\
\hline More siblings during the period & & 0,3418 & 0,1834 & 0,0620 & & 0,5473 & 0,1813 & 0,0030 & & 1,2091 & 0,1800 & 0,0000 \\
\hline \multicolumn{13}{|l|}{ Reference: Parents in the county 1-2 years } \\
\hline Parents in the country 3-4 years & & $-0,3481$ & 0,1935 & 0,0720 & & $-0,4422$ & 0,1954 & 0,0240 & & $-0,3198$ & 0,1938 & 0,0990 \\
\hline Parents in the country 5-6 years & & $-0,4239$ & 0,2321 & 0,0680 & & $-0,4775$ & 0,2444 & 0,0510 & & $-0,2101$ & 0,2483 & 0,3970 \\
\hline Parents in the country 7-8 years & & $-0,7342$ & 0,3287 & 0,0260 & & $-0,7776$ & 0,3449 & 0,0240 & & $-0,6188$ & 0,3434 & 0,0720 \\
\hline Parents in the country 9 or more years & & $-1,1237$ & 0,3143 & 0,0000 & & $-0,5809$ & 0,2814 & 0,0390 & & $-0,8437$ & 0,2938 & 0,0040 \\
\hline No mother & & $-0,0818$ & 0,6948 & 0,9060 & & $-0,1427$ & 0,6955 & 0,8370 & & 0,5394 & 0,6206 & 0,3850 \\
\hline No father & & 0,4486 & 0,4347 & 0,3020 & & 0,8236 & 0,4661 & 0,0770 & & 1,9666 & 0,4724 & 0,0000 \\
\hline Mother Secondary education le 2 years & & $-0,0690$ & 0,2013 & 0,7320 & & $-0,1363$ & 0,2041 & 0,5040 & & 0,0760 & 0,2051 & 0,7110 \\
\hline Mother Secondary education ge 3 years & & 0,0994 & 0,2971 & 0,7380 & & $-0,4994$ & 0,3594 & 0,1650 & & 0,1976 & 0,3545 & 0,5770 \\
\hline Mother University lt 3 years & & $-0,4215$ & 0,2587 & 0,1030 & & $-0,2523$ & 0,2547 & 0,3220 & & $-0,3005$ & 0,2840 & 0,2900 \\
\hline Mother University ge 3 years & & $-0,8690$ & 0,4875 & 0,0750 & & $-0,7412$ & 0,4736 & 0,1180 & & $-0,4250$ & 0,5185 & 0,4120 \\
\hline Mother No education infomation & & 0,4286 & 0,3557 & 0,2280 & & 0,5045 & 0,3609 & 0,1620 & & 0,8692 & 0,3309 & 0,0090 \\
\hline Father Secondary education le 2 years & & 0,0016 & 0,2090 & 0,9940 & & 0,2599 & 0,2105 & 0,2170 & & $-0,3517$ & 0,2099 & 0,0940 \\
\hline Father Secondary education ge 3 years & & $-0,1833$ & 0,3038 & 0,5460 & & 0,2532 & 0,3020 & 0,4020 & & $-0,6768$ & 0,3447 & 0,0500 \\
\hline Father University lt 3 years & & $-0,1601$ & 0,2498 & 0,5220 & & 0,1787 & 0,2528 & 0,4800 & & $-0,8453$ & 0,2754 & 0,0020 \\
\hline Father University ge 3 years & & $-0,2217$ & 0,3609 & 0,5390 & & 0,0444 & 0,3756 & 0,9060 & & $-0,7491$ & 0,3965 & 0,0590 \\
\hline Father No education infomation & & 0,6908 & 0,3621 & 0,0560 & & 0,6505 & 0,3772 & 0,0850 & & $-0,1280$ & 0,3840 & 0,7390 \\
\hline Unemployed in the LLM in 1993 & & 0,0381 & 0,0722 & 0,5970 & & 0,0717 & 0,0739 & 0,3320 & & 0,1845 & 0,0731 & 0,0120 \\
\hline _cons & & $-0,9863$ & 0,8278 & 0,2330 & & 0,6044 & 0,8396 & 0,4720 & & $-1,3561$ & 0,8457 & 0,1090 \\
\hline
\end{tabular}


Table A.9. Multinomial Logit estimating number of 3-year periods in persistent poverty. Persistent poverty in 0 periods is the comparison group. Native born parents. Sweden.

\begin{tabular}{|c|c|c|c|c|c|c|c|c|c|c|c|c|}
\hline & 1 & Coef. & Std. & $\mathbf{P}>|\mathbf{z}|$ & 2 & Coef. & Std. & $\mathbf{P}>|\mathbf{z}|$ & 3 & Coef. & Std. & $\mathbf{P}>|\mathbf{z}|$ \\
\hline Parent's age in 1993 & & 0,0111 & 0,0086 & 0,1970 & & 0,0195 & 0,0121 & 0,1080 & & 0,0420 & 0,0137 & 0,0020 \\
\hline Single parent in 1993 & & 0,3299 & 0,1118 & 0,0030 & & $-0,1396$ & 0,1745 & 0,4230 & & $-0,6107$ & 0,2242 & 0,0060 \\
\hline More than 2 children & & 0,8148 & 0,1023 & 0,0000 & & 1,3943 & 0,1428 & 0,0000 & & 1,3256 & 0,1637 & 0,0000 \\
\hline Child 0-3 years of age in 1993 & & 0,1675 & 0,1070 & 0,1170 & & 0,1312 & 0,1495 & 0,3800 & & 0,4747 & 0,1777 & 0,0080 \\
\hline More siblings during the period & & 0,7535 & 0,1128 & 0,0000 & & 1,0065 & 0,1591 & 0,0000 & & 0,8248 & 0,1915 & 0,0000 \\
\hline \multirow{2}{*}{\multicolumn{2}{|c|}{ No mother }} & & & & & & & & & & 2284691, & \\
\hline & & 2,3089 & 1,5561 & 0,1380 & & 3,2587 & 1,4209 & 0,0220 & & $-27,6441$ & 0000 & 1,0000 \\
\hline No father & & 1,1844 & 0,4842 & 0,0140 & & 2,0573 & 0,5946 & 0,0010 & & 1,0446 & 0,5311 & 0,0490 \\
\hline Mother Secondary education le 2 years & & $-0,5509$ & 0,1127 & 0,0000 & & $-0,5490$ & 0,1573 & 0,0000 & & $-0,3747$ & 0,1805 & 0,0380 \\
\hline Mother Secondary education ge 3 years & & $-0,4476$ & 0,1632 & 0,0060 & & $-0,2974$ & 0,2221 & 0,1810 & & $-0,7528$ & 0,2990 & 0,0120 \\
\hline Mother University lt 3 years & & $-0,7938$ & 0,1655 & 0,0000 & & $-0,6841$ & 0,2311 & 0,0030 & & $-0,7350$ & 0,2707 & 0,0070 \\
\hline Mother University ge 3 years & & $-1,7525$ & 0,2734 & 0,0000 & & $-1,1975$ & 0,3416 & 0,0000 & & $-1,4969$ & 0,4320 & 0,0010 \\
\hline Mother No education infomation & & $-1,8425$ & 1,5004 & 0,2190 & & $-1,3445$ & 1,3628 & 0,3240 & & $-0,5449$ & 1,1601 & 0,6390 \\
\hline Father Secondary education le 2 years & & $-0,2774$ & 0,1111 & 0,0130 & & $-0,3481$ & 0,1522 & 0,0220 & & $-0,5501$ & 0,1804 & 0,0020 \\
\hline Father Secondary education ge 3 years & & $-0,4416$ & 0,1725 & 0,0100 & & $-0,6191$ & 0,2405 & 0,0100 & & $-0,4581$ & 0,2557 & 0,0730 \\
\hline Father University lt 3 years & & $-0,8561$ & 0,1933 & 0,0000 & & $-1,3152$ & 0,2997 & 0,0000 & & $-1,4751$ & 0,3660 & 0,0000 \\
\hline Father University ge 3 years & & $-0,7500$ & 0,2084 & 0,0000 & & $-2,0284$ & 0,4141 & 0,0000 & & $-2,9981$ & 0,7321 & 0,0000 \\
\hline Father No education infomation & & 0,0274 & 0,4764 & 0,9540 & & 0,2470 & 0,5929 & 0,6770 & & 1,7806 & 0,5047 & 0,0000 \\
\hline Unemployed in the municipality in 1993 & & $-0,0158$ & 0,0412 & 0,7020 & & 0,0188 & 0,0561 & 0,7370 & & $-0,0075$ & 0,0652 & 0,9080 \\
\hline _cons & & $-2,8856$ & 0,5017 & 0,0000 & & $-4,3814$ & 0,6922 & 0,0000 & & $-5,3356$ & 0,8026 & 0,0000 \\
\hline
\end{tabular}

\footnotetext{
${ }^{\mathrm{i}}$ An earlier verson of the paper was presented at the $29^{\text {th }}$ General Conference of The International Association for Research in Income and Wealth, Joensuu, Finland, August 20 - 26 2006. We thank Kathleen S. Short for useful comments.
} 